\title{
Surgical treatment of right-sided infective endocarditis
}

James C. Witten, BA, ${ }^{\mathrm{a}}$ Syed T. Hussain, MD, ${ }^{\mathrm{b}}$ Nabin K. Shrestha, MD, ${ }^{\mathrm{c}}$ Steven M. Gordon, MD, Penny L. Houghtaling, MS, ${ }^{\mathrm{d}}$ Faisal G. Bakaeen, MD, ${ }^{\mathrm{b}}$ Brian Griffin, MD, ${ }^{\mathrm{e}}$ Eugene H. Blackstone, MD, ${ }^{\mathrm{b}, \mathrm{d}}$ and Gösta B. Pettersson, MD, $\mathrm{PhD}^{\mathrm{b}}$

\section{ABSTRACT}

Objective: Right-sided infective endocarditis is increasing because of increasing prevalence of predisposing conditions, and the role and outcomes of surgery are unclear. We therefore investigated the surgical outcomes for right-sided infective endocarditis.

Methods: From January 2002 to January 2015, 134 adults underwent surgery for right-sided infective endocarditis. Patients were grouped according to predisposing condition. Hospital outcomes, time-related death, and reoperation for infective endocarditis were analyzed.

Results: A total of 127 patients (95\%) had tricuspid valve and 7 patients $(5 \%)$ pulmonary valve infective endocarditis; 66 patients (49\%) had isolated right-sided infective endocarditis, and 68 patients $(51 \%)$ had right- and leftsided infective endocarditis. Predisposing conditions included injection drug use $(30 \%)$, cardiac implantable devices $(26 \%)$, chronic vascular access $(19 \%)$, and other/none $(25 \%)$. One native tricuspid valve was excised, $76 \%$ were repaired or reconstructed, and $23 \%$ were replaced. Intensive care unit and postoperative hospital stays were similar among groups. Injection drug users had the best early survival (no hospital mortality), and patients with chronic vascular access had the worst late survival (18\% at 5 years). Survival was worst for concomitant mitral valve versus isolated right-sided infective endocarditis or concomitant aortic valve infective endocarditis. Survival after tricuspid valve replacement was worse than after repair/reconstruction. Estimated glomerular filtration rate was the strongest risk factor for death, not predisposing condition. Eleven patients underwent 12 reoperations for infective endocarditis; more reoperations occurred in injection drug users $(P=.03)$.

Conclusions: Overall outcomes after surgery are variable and affected by patient condition, not predisposing condition. Injection drug use carries a higher risk of reoperation for infective endocarditis. Earlier surgery may permit more valve repairs and improve outcomes. Whenever possible, tricuspid valve replacement

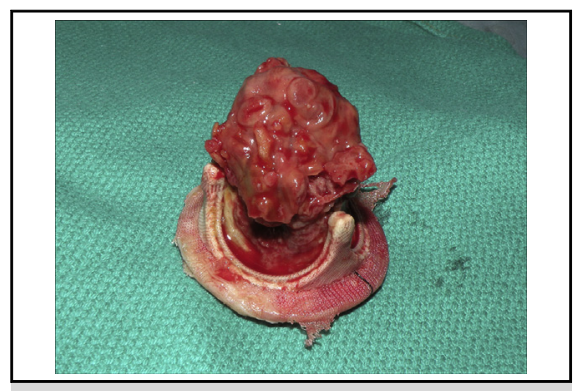

Large prosthetic tricuspid valve vegetation causing overwhelming septic pulmonary emboli.

\section{Central Message}

Increasing prevalence of right-sided endocarditis is concerning, and the role and timing of surgery remain unclear. Surgical outcomes are more affected by comorbidities than predisposing conditions.

\section{Perspective}

Right-sided IE is increasing secondary to the increase in predisposing conditions. The role and outcomes of surgery are unclear. Understanding that comorbidities drive mortality risk and that mortality and prevalence of reoperation are low may justify earlier surgery and lead to more tricuspid valve repairs and better outcomes.

See Commentaries on pages 1428 and 1430 . should be avoided. (J Thorac Cardiovasc Surg 2019;157:1418-27)

Infective endocarditis (IE) carries high morbidity and mortality and most frequently affects the left side of the heart; in contrast, right-sided IE, which accounts for
$5 \%$ to $10 \%$ of cases, is thought to be more benign, with most cases managed medically. It mainly affects the tricuspid valve, ${ }^{1-4}$ with valve replacement
From the ${ }^{a}$ Education Institute, Cleveland Clinic Lerner College of Medicine, Cleveland, Ohio; ${ }^{\mathrm{b}} \mathrm{Heart}$ and Vascular Institute, Department of Thoracic and Cardiovascular Surgery; ${ }^{\mathrm{c}}$ Medicine Institute, Department of Infectious Disease; ${ }^{\mathrm{d}}$ Research Institute, Department of Quantitative Health Sciences; and ${ }^{\mathrm{e}}$ Medicine Institute, Department of Cardiovascular Medicine, Cleveland Clinic, Cleveland, Ohio.

This study was funded in part by the John and Rosemary Brown Endowed Chair in Cardiovascular Medicine, the Drs Sidney and Becca Fleischer Heart and Vascular Education Chair, the Peter and Elizabeth C. Tower and Family Endowed Chair in Cardiothoracic Research, James and Sharon Kennedy, the Slosburg Family Charitable Trust, Stephen and Saundra Spencer, and Martin Nielsen.
Read at the American Association for Thoracic Surgery Mitral Conclave, New York, New York, April 27-28, 2017.

Received for publication Feb 15, 2018; revisions received July 18, 2018; accepted for publication July 30, 2018; available ahead of print Nov 30, 2018.

Address for reprints: Gösta B. Pettersson, MD, PhD, Department of Thoracic and Cardiovascular Surgery, Cleveland Clinic, 9500 Euclid Ave/Desk J4-1, Cleveland, OH 44195 (E-mail: petterg@ @cf.org). $0022-5223 / \$ 36.00$

Copyright (C) 2018 Published by Elsevier Inc. on behalf of The American Association for Thoracic Surgery

https://doi.org/10.1016/j.jtcvs.2018.07.112 


\section{Abbreviation and Acronym}

$\mathrm{IE}=$ infective endocarditis

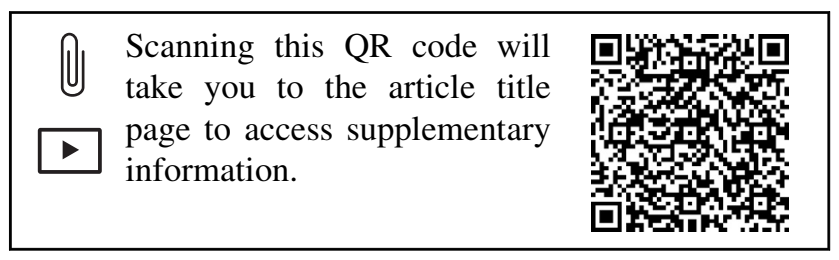

performed in most surgical cases ${ }^{5}$; pulmonary valve involvement is rare. . $^{2,3,6}$

Injection drug use is the leading cause of right-sided IE in the western world, and its prevalence is increasing in the current opioid epidemic. ${ }^{7}$ However, prevalence of other predisposing conditions is also on the rise, as more cardiac devices are implanted in the right heart, including pacemakers, implantable cardioverter-defibrillators, and resynchronization devices, and because use of central catheters, arteriovenous fistulas for renal dialysis, and repaired congenital heart disease is increasing. ${ }^{3}$ Even the spectrum of causative organisms is changing. ${ }^{3,4,8}$ The specific predisposing condition is sometimes used to advocate for or against surgery., ${ }^{9,10}$

Most previous studies of right-sided IE have focused on injection drug use, with only a few discussing the changing profile of the disease and contemporary results of surgical treatment. ${ }^{1,7,9,11}$ There is also a paucity of data on isolated right-sided IE versus combined right- and leftsided IE, which may affect outcomes. ${ }^{1}$ We therefore (1) reviewed predisposing condition, patient characteristics, microbiology, and cardiac pathology; (2) identified risk factors for poor outcomes; and (3) assessed IE recurrence in patients who underwent surgery for right-sided IE over the past decade at Cleveland Clinic.

\section{PATIENTS AND METHODS \\ Patients}

From January 1, 2002, to January 1, 2015, 1292 consecutive adults underwent surgery for IE at Cleveland Clinic, of whom $134(10 \%)$ had rightsided IE. All met modified Duke criteria for definite IE. ${ }^{12}$

\section{Data Sources and Abstraction}

IE surgical pathology was coded as previously described using medical records, operative reports, and echocardiography reports. ${ }^{13}$ The Cardiovascular Information Registry was queried for patient characteristics, operative details, and postoperative course. Data used for the study were approved for use in research by the Cleveland Clinic Institutional Review Board, with patient consent waived.

\section{Predisposing Condition}

Patients were categorized into 1 of 4 predisposing condition groups: injection drug use, cardiac implantable device, chronic vascular access, and other/none. Patients with cardiac implantable devices were considered to have right-sided IE when the tricuspid valve was convincingly infected.

The other/none group $(n=33)$ comprised 3 subgroups: (1) congenital heart anomalies $(10 / 33,30 \%),(2)$ invasive fistula tracts from left-sided IE $(8 / 33,24 \%)$, and (3) IE without clear predisposing conditions $(15 / 33$, $46 \%$ ) (Table E1). Presence of prosthetic valves was found in all groups (Table 1).

\section{Indications for Surgery}

Factors persuasive for surgery (indications) were identified by review of hospital records and operative reports. They included severe valvular regurgitation from valve damage or destruction or prosthetic valve dehiscence; right heart failure with peripheral edema, hepatic congestion, right ventricular systolic dysfunction, and right ventricular dilatation; left heart failure with pulmonary congestion, reduced ejection fraction, left ventricular dilatation, and low cardiac index; septic emboli; large vegetations greater than $15 \mathrm{~mm}$ in 1 direction on echocardiogram; failure of medical therapy with sepsis lasting more than 5 to 7 days; fistulas, abscesses, or pseudoaneurysm formation; and a conduction defect such as worsening degree of heart block. In patients with both right- and left-sided IE, the left-sided disease often provided the main indications for surgery.

\section{Microorganisms}

Causative organisms were retrieved from microbiologic laboratory reports and validated by infectious disease specialists. Information on causative organism included universal bacterial polymerase chain reaction results.

\section{Infective Endocarditis Management and Surgery}

IE management was by a multidisciplinary team comprising infectious disease physicians, cardiologists, cardiothoracic surgeons, and other specialists. This team-based approach was ongoing throughout the study period and reflects a culture existing ahead of guidelines ${ }^{14,15}$; it was folded into the 2017 American Association for Thoracic Surgery guidelines for surgical treatment of IE. ${ }^{16}$

Once the patient has an indication for operation, surgery is expedited. Our surgical approach is debridement of all infected tissues and foreign material, followed by generous irrigation. Local antiseptics and antibiotics are used sparingly. Tricuspid valve repair or reconstruction is performed whenever possible using a variety of reconstruction techniques, including use of autologous pericardium and artificial chords for leaflet reconstruction (Video 1) with or without suture or ring anuloplasty. Rather than replacing the valve with a prosthetic device, important residual TR was frequently accepted. When replacement is deemed unavoidable, we use a bioprosthesis. Valvectomy without replacement was used once in this series.

\section{End Points}

End points were all-cause mortality after surgery and recurrent IE. Follow-up data were obtained through medical record review of subsequent examinations at Cleveland Clinic, mailed Institutional Review Boardapproved questionnaires, and telephone contact. All patients were followed for vital and recurrence status within 6 months of the cross-sectional closing date (Figure E1). Median follow-up of survivors was 5.2 years, with $25 \%$ of survivors followed more than 8 years and $10 \%$ more than 10 years.

Patients with recurrent IE met the modified Duke criteria for IE subsequent to discharge after the index hospitalization. Recurrence was categorized as IE "relapse" or "reinfection" based on timing and microbiology. If microbiology was consistent between episodes and recurrence occurred within 6 months after index surgery, it was considered disease relapse; if microbiology was disparate between episodes, or recurrence occurred more than 6 months after index operation, it was classified as reinfection. Other outcomes included in-hospital postoperative complications, defined according to The Society of Thoracic Surgeons Adult Cardiac Surgery database. ${ }^{17}$ 
TABLE 1. Baseline characteristics of patients undergoing surgery for right-sided infective endocarditis according to predisposing condition

\begin{tabular}{|c|c|c|c|c|c|}
\hline \multirow[b]{2}{*}{ Characteristics } & \multicolumn{4}{|c|}{ Predisposing condition } & \multirow[b]{2}{*}{$\boldsymbol{P}$} \\
\hline & $\begin{array}{l}\text { Injection drug use } \\
(n=40) \text { No. }(\%) \text { or } \\
\text { median [15th, 85th } \\
\text { percentiles] }\end{array}$ & $\begin{array}{c}\text { Cardiac implantable } \\
\text { device }(\mathbf{n}=35) \\
\text { No. }(\%) \text { or median } \\
{[15 \text { th }, 85 \text { th percentiles }]}\end{array}$ & $\begin{array}{c}\text { Chronic vascular } \\
\text { access }(n=26) \\
\text { No. }(\%) \text { or median } \\
{[15 \text { th }, 85 \text { th percentiles }]}\end{array}$ & $\begin{array}{c}\text { Other/none }(n=33) \\
\text { No. }(\%) \text { or median } \\
\text { [15th, 85th percentiles] }\end{array}$ & \\
\hline \multicolumn{6}{|l|}{ Demographics } \\
\hline Age (y) & $34[26,49]$ & $62[43,77]$ & $50[37,62]$ & $55[30,69]$ & $<.0001$ \\
\hline Female & $22(55)$ & $11(31)$ & $10(38)$ & $14(42)$ & .2 \\
\hline Body mass index $\left(\mathrm{kg} / \mathrm{m}^{2}\right)$ & $22[20,28]$ & $27[22,39]$ & $27[22,36]$ & $26[21,31]$ & .0009 \\
\hline \multicolumn{6}{|l|}{ Presentation } \\
\hline NYHA functional class III-IV & $11 / 33(33)$ & $11 / 33(33)$ & $11 / 24(46)$ & $13 / 31(42)$ & .3 \\
\hline Emergency operation & $4(10)$ & $1(2.9)$ & $0(0)$ & $2(6.1)$ & .3 \\
\hline Prior stroke & $6(15)$ & $6(17)$ & $7(27)$ & $4(12)$ & .5 \\
\hline Prior myocardial infarction & $3(7.5)$ & $13(37)$ & $5(19)$ & $5(15)$ & .01 \\
\hline $\begin{array}{l}\text { Acute or chronic renal disease } \\
\text { requiring dialysis }\end{array}$ & $1(2.5)$ & $2(5.7)$ & $14(54)$ & $1(3.0)$ & $<.0001$ \\
\hline Preoperative eGFR $\left(\mathrm{mL} / \mathrm{min} / 1.73 \mathrm{~m}^{2}\right)$ & $80[44,144]$ & $68[37,99]$ & $16[10,98]$ & $75[35,108]$ & $<.0001$ \\
\hline Iatrogenic source of infection & $4(10)$ & $2(5.7)$ & $0(0)$ & $8(24)$ & .01 \\
\hline \multicolumn{6}{|l|}{ Cardiac comorbidity } \\
\hline Prior IE & $8(20)$ & $2(5.7)$ & $2(7.7)$ & $3(9.1)$ & .2 \\
\hline Prior complete heart block or pacer & $3(7.5)$ & $14 / 34(41)$ & $3 / 24(13)$ & $3 / 32(9.4)$ & .0005 \\
\hline Prior cardiac operations & & & & & .5 \\
\hline 0 & $29(73)$ & $17(49)$ & $16(62)$ & $18(55)$ & \\
\hline 1 & $8(20)$ & $11(31)$ & $7(27)$ & $11(33)$ & \\
\hline 2 & $3(7.5)$ & $6(17)$ & $3(12)$ & $2(6.1)$ & \\
\hline $3+$ & $0(0)$ & $1(2.9)$ & $0(0)$ & $2(6.1)$ & \\
\hline \multicolumn{6}{|l|}{ Valve affected } \\
\hline Aortic & $7(18)$ & $8(23)$ & $10(38)$ & $20(61)$ & .0006 \\
\hline Mitral & $12(30)$ & $7(20)$ & $11(42)$ & $11(33)$ & .3 \\
\hline Tricuspid & $39(98)$ & $35(100)$ & $26(100)$ & $27(82)$ & .002 \\
\hline Pulmonary & $1(2.5)$ & $0(0)$ & $0(0)$ & $6(18)$ & .002 \\
\hline Right-sided IE only & $23(58)$ & $23(66)$ & $10(38)$ & $11(33)$ & .02 \\
\hline \multicolumn{6}{|l|}{ Prosthetic valve endocarditis } \\
\hline Any valve & $11(28)$ & $7(20)$ & $6(23)$ & $11(33)$ & 6 \\
\hline Aortic valve & $4(10)$ & $6(17)$ & $3(12)$ & $6(18)$ & .7 \\
\hline Mitral valve & $1(2.5)$ & $2(5.7)$ & $3(12)$ & $2(6.1)$ & .5 \\
\hline Tricuspid valve & $8(20)$ & $0(0)$ & $0(0)$ & $2(6.1)$ & .003 \\
\hline Pulmonary valve & $1(2.5)$ & $0(0)$ & $0(0)$ & $3(9.1)$ & .10 \\
\hline Infectious fistula from left to right & $2(5.0)$ & $2(5.7)$ & $4(15)$ & $8(24)$ & .02 \\
\hline \multicolumn{6}{|l|}{ Noncardiac comorbidity } \\
\hline Peripheral arterial disease & $3(7.5)$ & $7(20)$ & $9(35)$ & $3(9.1)$ & .02 \\
\hline Immunosuppression & $0(0)$ & $1(2.9)$ & $6(23)$ & $1(3.0)$ & .0006 \\
\hline Hypertension & $18(45)$ & $21(60)$ & $22(85)$ & $18(55)$ & .01 \\
\hline Pharmacologically treated diabetes & $2(5.0)$ & $10 / 34(29)$ & $11(42)$ & $8 / 32(25)$ & .004 \\
\hline
\end{tabular}

NYHA, New York Heart Association; $e G F R$, estimated glomerular filtration rate; $I E$, infective endocarditis.

\section{Data Analysis}

All analyses were performed using SAS statistical software (version 9.4; SAS Institute, Inc, Cary, NC). Continuous variables are summarized as mean \pm standard deviation or as equivalent 15 th $/ 50$ th $/ 85$ th percentiles when values were skewed; comparisons were made using the Wilcoxon rank-sum test. Categoric variables are summarized as frequencies and percentages; comparisons were made using the chi-squared test or Fisher's exact test when frequency was less than 5 . Uncertainty is expressed by confidence limits equivalent to \pm 1 standard error $(68 \%)$.

Time-related all-cause mortality and IE recurrence were estimated nonparametrically using the Kaplan-Meier method and the Andersen method for competing risks, ${ }^{18}$ and parametrically using a multiphase nonproportional hazards model. ${ }^{19}$ Multivariable analysis was performed in the hazard function domain, in which variables modulating each hazard phase were considered simultaneously. Variable selection from among those listed in Appendix E1, with a $P$-value criterion for retention of .05 or less, used a machine-learning bootstrap-aggregation method involving unsupervised variable selection based on 1000 bootstrap samples. ${ }^{20,21}$ Frequency of occurrence of single and closely related clusters of factors selected in these analyses was tabulated and indicated reliability of each variable. Variables with bootstrap reliability of $50 \%$ or greater were retained in the final model. Thereafter, predisposing conditions were forced into the 


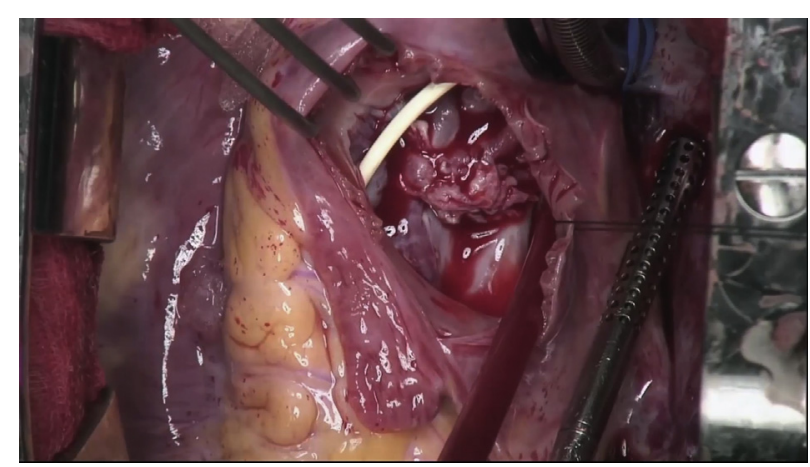

VIDEO 1. Debridement and reconstruction of the tricuspid valve. Reconstruction is performed using untreated autologous pericardium and artificial chords. Video available at: https://www.jtcvs.org/article/S00225223(18)32475-9/fulltext.

final model to assess risk-adjusted estimates, regardless of statistical significance.

\section{RESULTS}

\section{Right-Sided Infective Endocarditis}

Of the 134 patients, $127(95 \%)$ had tricuspid valve and 7 $(5 \%)$ pulmonary valve IE. Sixty-seven patients $(50 \%)$ had isolated right-sided IE, and $67(50 \%)$ had right- and leftsided IE (Figure E2).

\section{Infective Endocarditis According to Predisposing Condition}

The predisposing condition was injection drug use in 40 patients $(30 \%)$, cardiac implantable device in 35 patients (26\%), chronic vascular access in 26 patients $(19 \%)$, and other/none in 33 patients $(25 \%)$. Injection drug users were the youngest group. Those with cardiac implantable devices often had complete heart block ( $41 \%$ of group). Those with chronic vascular access had more comorbidities, and $54 \%$ were on dialysis.

New York Heart Association functional class, emergency status at operation, and history of stroke were similar across predisposing conditions, as was history of IE, prior cardiac surgery, and prosthetic valve IE of any valve (Table 1 ). Prosthetic valves were frequent across groups $(20 \%-33 \%)$, with prosthetic tricuspid valve IE most common in injection drug users $(20 \%)$. Injection drug users and patients with cardiac implantable devices were more likely to have isolated rightsided IE, whereas those with chronic vascular access and those in the other/none group were more likely to have rightand left-sided IE. The pulmonary valve was particularly affected in the other/none group (18\%), including 3 native pulmonary valve infections, 2 pulmonary allograft infections, and 1 bioprosthetic valved-conduit infection (Table E2).

Mitral valve involvement was similar across predisposing conditions; however, concomitant aortic valve IE was most common in the other/none group (61\%). Right-sided infection occurred through invasive fistula tracts from the left side in $15(22 \%)$.

\section{Indications for Surgery}

Severe valve regurgitation, heart failure, and septic emboli were the most common clinical sequelae persuasive for surgery (Table 2). Large vegetations and medical failure were also often indications for surgery. A combination of large vegetations and septic pulmonary emboli were most commonly cited in injection drug users. For patients with cardiac implantable devices, large vegetations were the most common indications. Large vegetations were least common in the other/none group.

\section{Microorganisms}

The most common genus was staphylococcus, with Staphylococcus aureus (38\%) and coagulase-negative staphylococci $(23 \%)$ together infecting $61 \%$ of the cohort (Table 2). Microbiology varied by predisposing condition: Injection drug users were predominantly infected by $S$ aureus, whereas the other/none group had many atypical organisms. Nearly half $(22 / 54,41 \%)$ of $S$ aureus infections in the cohort were caused by methicillin-resistant organisms. All enterococcus isolates were vancomycin-susceptible. Four patients had fungal IE (Table E3).

\section{Infective Endocarditis Surgery}

Surgery consisted of debridement and repair/reconstruction or replacement of damaged valves (Table 3). In patients with native tricuspid valve involvement, $90(76 \%)$ had valve repair/reconstruction and $27(23 \%)$ had prosthetic valve replacement. One patient had a subtotal valvectomy without replacement. In addition to leaflet reconstructions and artificial chords, an anuloplasty ring was used in 27 patients $(30 \%)$ and suture anuloplasty in the remaining tricuspid valve repair/reconstructions. Tricuspid regurgitation at discharge was none or mild in the majority of patients receiving repair/reconstruction; however, $21 \%$ left the operating room with moderate and $23 \%$ with severe TR (Figure E3). During 5 years of echocardiographic follow-up, less than $10 \%$ experienced worsening of their regurgitation.

Replacement was similar across predisposing conditions. Tricuspid valve replacements were with stented bioprostheses except for 1 pulmonary allograft. The pulmonary valve was repaired in 2 patients $(30 \%)$ and replaced with a pulmonary allograft in 5 patients $(70 \%)$.

Patients in the other/none group had the shortest overall hospital stay (Table E4). Acute postoperative renal failure occurred in $23 \%$ of patients with cardiac implantable devices and $24 \%$ of those in the other/none predisposing condition group (Table E4). Prolonged ventilation was common across all groups. Heart block developed in $9(15 \%)$ of those patients with isolated tricuspid valve IE $(\mathrm{n}=62)$ (Table E5). These heart blocks occurred in patients who 
TABLE 2. Disease characteristics persuasive of need for surgery (indications)

\begin{tabular}{|c|c|c|c|c|c|}
\hline \multirow[b]{2}{*}{ Characteristics } & \multicolumn{4}{|c|}{ Predisposing condition } & \multirow[b]{2}{*}{$\boldsymbol{P}$} \\
\hline & $\begin{array}{l}\text { Injection drug use } \\
(n=40) \text { No. }(\%)\end{array}$ & $\begin{array}{c}\text { Cardiac implantable } \\
\text { device }(n=35) \text { No. }(\%)\end{array}$ & $\begin{array}{c}\text { Chronic vascular } \\
\text { access }(n=26) \text { No. }(\%)\end{array}$ & $\begin{array}{c}\text { Other/none } \\
(n=33) \text { No. }(\%)\end{array}$ & \\
\hline \multicolumn{6}{|l|}{ Persuasive clinical finding* } \\
\hline Severe valve regurgitation & $29(73)$ & $16(46)$ & $19(73)$ & $22(67)$ & .06 \\
\hline Right heart failure & $12(30)$ & $8(23)$ & $7(27)$ & $8(24)$ & .9 \\
\hline Left heart failure & $9(23)$ & $10(29)$ & $10(38)$ & $17(52)$ & .06 \\
\hline Septic emboli & $31(78)$ & $9(26)$ & $12(46)$ & $16(48)$ & .0001 \\
\hline Pulmonary & $28(70)$ & $8(23)$ & $11(42)$ & $13(39)$ & .0005 \\
\hline Systemic & $7(18)$ & $1(2.9)$ & $3(12)$ & $5(15)$ & .2 \\
\hline Cerebral & $9(23)$ & $1(2.9)$ & $2(7.7)$ & $3(9.1)$ & .06 \\
\hline Large vegetations & $24(60)$ & $21(60)$ & $12(46)$ & $10(30)$ & .04 \\
\hline Medical failure/uncontrolled infections & $11(28)$ & $9(26)$ & $8(31)$ & $14(42)$ & .4 \\
\hline Valve destruction or damage & $7(18)$ & $6(17)$ & $5(19)$ & $9(27)$ & .7 \\
\hline Prosthetic valve dehiscence & $4(10)$ & $6(17)$ & $6(23)$ & $6(18)$ & 6 \\
\hline Fistula, abscess, pseudoaneurysm & $4(10)$ & $7(20)$ & $5(19)$ & $10(30)$ & .19 \\
\hline $\mathrm{PFO} / \mathrm{ASD} / \mathrm{VSD}$ & $3(7.5)$ & $3(8.6)$ & $1(3.8)$ & $8(24)$ & .02 \\
\hline Worsening heart block/conduction defect & $3(7.5)$ & $2(5.7)$ & $3(12)$ & $4(12)$ & .8 \\
\hline Microbiology & & & & & .0007 \\
\hline Staphylococcus aureus & $27(68)$ & $10(29)$ & $9(35)$ & $8(24)$ & \\
\hline Coagulase-negative staphylococcus $\dagger$ & $2(5.0)$ & $15(43)$ & $8(31)$ & $8(24)$ & \\
\hline Enterococcus & $1(2.5)$ & $3(8.6)$ & $1(3.8)$ & $3(9.1)$ & \\
\hline Viridans group streptococcus & $4(10)$ & $0(0)$ & $1(3.8)$ & $2(6.1)$ & \\
\hline Other & $0(0)$ & $2(5.7)$ & $4(15)$ & $8(24)$ & \\
\hline Polymicrobial $\S$ & $2(5.0)$ & $1(2.9)$ & $1(3.8)$ & $0(0)$ & \\
\hline Fungus $\|$ & $1(2.5)$ & $2(5.7)$ & $1(3.8)$ & $0(0)$ & \\
\hline Pathogen not identified & $3(7.5)$ & $2(5.7)$ & $1(3.8)$ & $4(12)$ & \\
\hline
\end{tabular}

PFO/ASD/VSD, Patent foramen ovale/atrial septal defect/ventricular septal defect. *Not mutually exclusive. $\dagger$ Includes 3 cases of $S$ lugdunensis, 1 in chronic vascular access and 2 in cardiac implantable device. $\ddagger$ Includes Abiotropha defectiva, Achromobacter xylosoxidans, Bartonella henselae, Cardiobacterium hominis, Brevibacterium otitidis, Enterobacter cloacae, Mycobacterium chenolae-abscessus complex, 2 Pseudomonas aeruginosa, Cutibacterium (formerly Propionibacterium) acnes, Proteus vulgaris, 2 Streptococcus pneumoniae, Streptococcus pyogenes. §Includes coagulase-negative staphylococcus and viridans group streptococcus; Pseudomonas aeruginosa and viridans group streptococcus; Candida albicans and Pseudomonas aeruginosa; coagulase-negative staphylococcus and Pseudomonas aeruginosa. ||Includes 1 Aspergillus fumigatus, 2 Candida albicans, and 1 Candida tropicalis.

underwent replacement of the tricuspid valve, aortic valve, or both, except for 1 who underwent tricuspid valve repair and closure of a ventricular septal defect.

\section{Mortality}

In-hospital mortality was $5.9 \%$, with no significant differences across predisposing conditions, although no injection drug user died in-hospital $(P=.18$, Table E4). Among 134 patients, 70 deaths occurred by end of follow-up. Risk of death was high during the first 6 months after surgery, followed by a slowly decreasing late hazard, which was similar across predisposing conditions (Figure $\mathrm{E} 4, A-C$ ).

Survival varied by predisposing condition (P[logrank $]=.009$; Figure 1). Injection drug users had the highest early survival (92\% at 6 months), and patients with chronic vascular access had the lowest early and late survival $(73 \%$ at 6 months, $18 \%$ at 5 years); 5 -year survival was $59 \%$ in patients with cardiac implantable devices and $69 \%$ in the other/none group. Survival in patients with isolated rightsided IE and left- and right-sided IE was similar when stratified by predisposing condition (Figure E5, $A$ and $B$ ). Survival was lower for patients with combined right- and left-sided IE than for those with isolated right-sided IE $(P=.03$; Figure E6). Patients with IE involving the mitral or mitral + aortic valves had worse survival than those with right- and left-sided IE involving the aortic valve or with right-sided IE only $(P=.002$; Figure 2$)$. Patients who underwent tricuspid valve repair/reconstruction had better survival than those undergoing tricuspid replacement (Figures 3 and E7).

On multivariable analysis, poor kidney function, tricuspid valve replacement at index operation, peripheral arterial disease, and mitral valve involvement affected late survival (Table E6), but predisposing condition was not an independent risk factor.

\section{Infective Endocarditis Relapse/Recurrence}

Thirteen patients developed recurrent IE 14 times, 5 relapses and 9 reinfections (Table E7). Eleven patients underwent 12 reoperations during follow-up, and 2 were treated 
TABLE 3. Operative details

\begin{tabular}{|c|c|c|c|c|c|}
\hline \multirow[b]{2}{*}{ Operation performed } & \multicolumn{4}{|c|}{ Predisposing condition } & \multirow[b]{2}{*}{$\boldsymbol{P}$} \\
\hline & $\begin{array}{l}\text { Injection drug use } \\
(\mathrm{n}=40) \text { No. }(\%)\end{array}$ & $\begin{array}{c}\text { Cardiac implantable } \\
\text { device }(n=35) \text { No. }(\%)\end{array}$ & $\begin{array}{l}\text { Chronic vascular access } \\
\quad(\mathbf{n}=26) \text { No. }(\%)\end{array}$ & $\begin{array}{c}\text { Other/none } \\
(\mathbf{n}=33) \text { No. }(\%)\end{array}$ & \\
\hline \multicolumn{6}{|l|}{ Tricuspid valve } \\
\hline Repair/reconstruction & $26(65)$ & $26(74)$ & $18(69)$ & $23(70)$ & .9 \\
\hline With anuloplasty ring & $6(23)$ & $6(24)$ & $11(61)$ & $4(17)$ & .02 \\
\hline Replacement & $14(35)$ & $9(26)$ & $8(31)$ & $6(18)$ & .4 \\
\hline \multicolumn{6}{|l|}{ Pulmonary valve } \\
\hline Repair & $0(0)$ & $0(0)$ & $0(0)$ & $2(6.1)$ & 6 \\
\hline Replacement & $1(3.0)$ & $0(0)$ & $0(0)$ & $4(12)$ & .6 \\
\hline \multicolumn{6}{|l|}{ Aortic valve } \\
\hline Repair & $1(2.5)$ & $1(2.9)$ & $1(3.8)$ & $1(3.0)$ & $>.9$ \\
\hline Replacement & $7(18)$ & $8(23)$ & $9(35)$ & $19(58)$ & .002 \\
\hline \multicolumn{6}{|l|}{ Mitral valve } \\
\hline Repair & $5(13)$ & $3(8.6)$ & $9(35)$ & $8(24)$ & .04 \\
\hline With anuloplasty ring & $4(80)$ & $1(25)$ & $4(44)$ & $6(75)$ & .8 \\
\hline Replacement & $8(20)$ & $4(11)$ & $4(15)$ & $6(18)$ & .8 \\
\hline $\begin{array}{l}\text { Epicardial pacemaker lead } \\
\text { placement }\end{array}$ & $15(38)$ & $21(60)$ & $6(23)$ & $11(33)$ & .02 \\
\hline
\end{tabular}

medically. Five-year freedom from recurrence was $87 \%$ (Figures E8 and E9). Nine of the 13 patients (69\%) were injection drug users, with 5-year freedom from recurrence of $76 \%$ compared with $93 \%$ for other predisposing conditions (Figure 4). Two recurrences were in patients with a history of IE surgery, similar to those without prior IE surgery (Figure E10). IE recurrence did not differ significantly between those who underwent tricuspid repair/reconstruction versus replacement.

\section{DISCUSSION}

\section{Principal Findings}

Patient characteristics differed across predisposing conditions. Surgical management focused on thorough

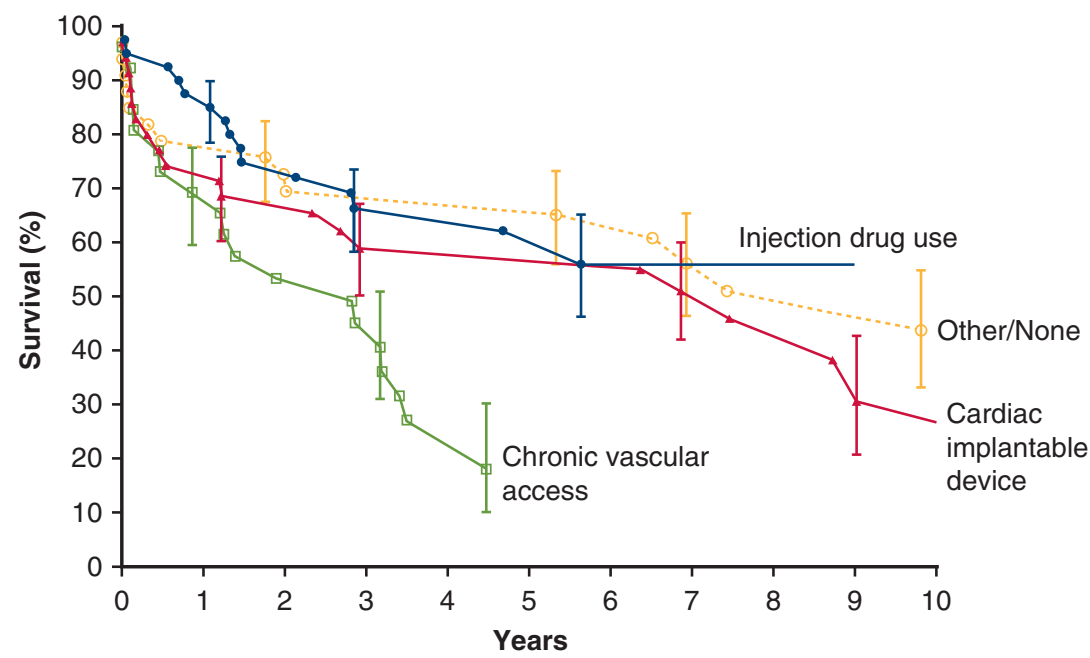

\begin{tabular}{lllllll} 
\# at risk & \multicolumn{7}{c}{ Years } \\
Drug use & 40 & 28 & 20 & 10 & 6 & 4 \\
CID & 35 & 24 & 19 & 16 & 9 & 5 \\
Vasc. access & 26 & 14 & 4 & 2 & - & - \\
Other/none & 33 & 24 & 20 & 16 & 10 & 5
\end{tabular}

FIGURE 1. Survival after surgery for right-sided IE stratified by predisposing condition. Each symbol represents a death and vertical bars $68 \%$ confidence limits equivalent to \pm 1 standard error. Number of patients at risk is shown periodically beneath the horizontal axis. The injection drug use group is denoted by blue line and filled circles, cardiac implantable device (CID) group is denoted by red line and triangles, chronic vascular access group is denoted by green line and squares, and other/none group is denoted by yellow dashed line and open circles. 


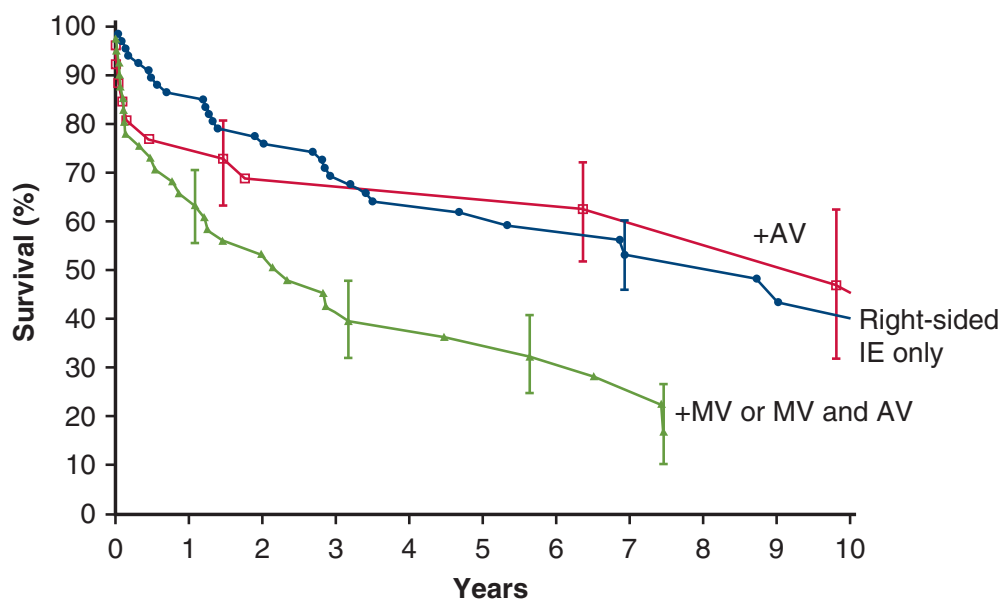

\# at risk

RSIE only

$+\mathrm{AV}$

67

51

33

$+\mathrm{MV}$ or $\mathrm{MV}+\mathrm{AV}$

26

17

15

22

13

10

41

21

14

12

9

3

FIGURE 2. Survival after surgery for right-sided IE stratified by valves affected. Format is as in Figure 1. Right-sided IE (RSIE)-only group is denoted by blue line and filled circles, right-sided IE + concomitant aortic valve ( $A V)$ IE group is denoted by red line and squares, and right-sided IE + concomitant mitral valve $(M V)$ or $\mathrm{MV}+\mathrm{AV}$ involvement is denoted by green line and triangles. IE, Infective endocarditis.

debridement and valve repair/reconstruction when possible, which was achieved in a high proportion of patients. Early and late mortality varied by predisposing condition; however, only poor kidney function, tricuspid valve replacement, peripheral arterial disease, and mitral valve involvement were risk factors. Relapse or recurrence of IE was uncommon except in injection drug users.

\section{Infective Endocarditis Predisposing Conditions}

IE involving right-sided valves has become an increasing problem with the steady increase in predisposing conditions, including doubling of injection heroin use in the last decade ${ }^{22}$ and accelerated use of cardiac implantable devices. $^{23}$ The makeup of predisposing condition groups in our study followed these reported trends, including younger

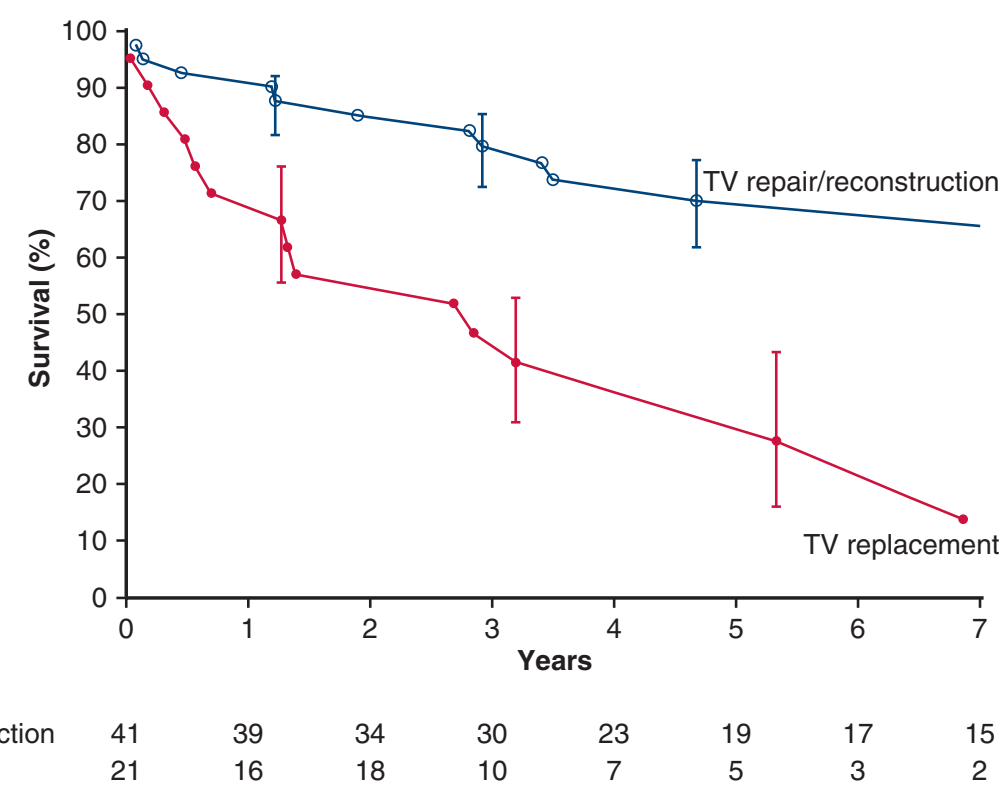

FIGURE 3. Survival after tricuspid repair/reconstruction or tricuspid replacement for tricuspid IE only. Format is as in Figure 1. TV, Tricuspid valve. 


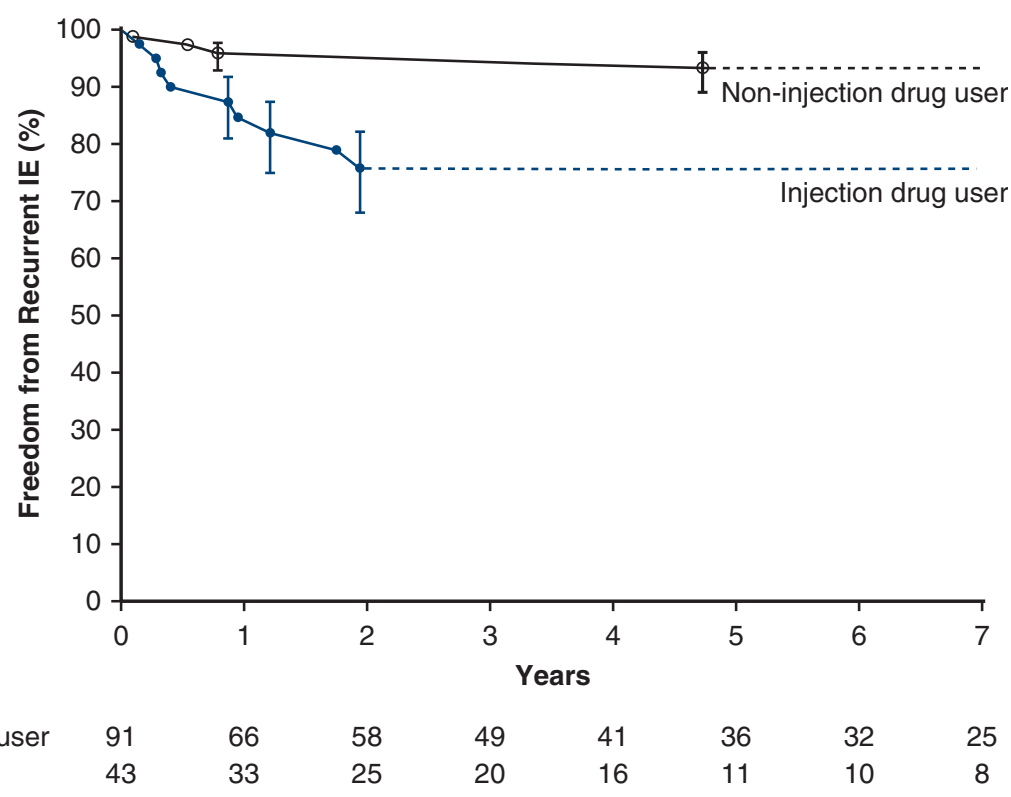

FIGURE 4. Freedom from relapse/recurrent IE after surgery for right-sided IE, stratified by injection drug use or not. Format is as in Figure 1. Injection drug use group is denoted by blue line and filled circles, and combined other groups are represented by black dashed line and open circles. IE, Infective endocarditis.

age for injection drug users and more comorbidities for patients with chronic vascular access. ${ }^{9,10}$

Manifestations of IE varied among predisposing conditions: Injection drug users were nearly as likely to have combined right- and left-sided IE as isolated right-sided IE. Those with chronic vascular access were more likely to have combined right- and left-sided IE. Conversely, those with a cardiac implantable device were almost twice as likely to have isolated right-sided IE.

The other/none group was heterogeneous. In some, congenital septal anomalies provided a pathway to seeding right-sided valves from left-sided IE. Another source in this group was invasion of left-sided IE through a fistula tract, usually from an infected aortic valve and root. Many also had a prosthetic aortic valve, the presence of which increases risk of invasive IE. ${ }^{24}$ This group also contained patients for whom no predisposing factor was identified, a trait more commonly found in isolated left-sided IE. ${ }^{25}$

\section{Indications for Surgery}

Surgical indications and intervention algorithms for leftsided IE are well established, but this is not true for rightsided IE. ${ }^{16}$ For right-sided IE, we operate for large vegetations to eliminate the source of infection, prevent further showering of lungs with septic emboli, and eliminate severe tricuspid valve regurgitation. Because moderate tricuspid regurgitation is well tolerated, optimal timing of intervention is difficult to estimate. When an operation is performed early in the course of disease, surgical risk is low.

With increasing septic pulmonary embolism burden, risk increases and the window of opportunity to intervene may close as pulmonary complications lead to a rapid decline in patient status. The lungs themselves can become a primary source of infection, causing persistent bacteremia. ${ }^{26}$ Most injection drug users in our series had septic pulmonary emboli, either alone or along with systemic emboli. In an otherwise healthy young patient, these often were persuasive for surgery. Injection drug use itself is also a direct source of pulmonary sepsis.

\section{Causative Organisms}

In injection drug users, $S$ aureus is the dominant organism (68\% in our series and $60 \%-90 \%$ in others). ${ }^{4}$ In our series, $S$ aureus was not a significant risk factor for death, which may be explained by more timely operations for these infections than for other pathogens and by the noninvasiveness of right-sided infections. ${ }^{24}$

\section{Infective Endocarditis Treatment}

Right-sided IE is typically treated conservatively. $1,11,27$ When indicated, however, surgical treatment of rightsided IE can be performed with good early, mid-term, and long-term results. ${ }^{1,4,5,28,29}$

Our experience supports making every effort to avoid replacing the tricuspid valve, with valve replacement performed only if repair is impossible. ${ }^{1,28,29}$ Valve repair may include reconstruction procedures such as replacement of large portions of the leaflets with autologous pericardium or other patch material and support with artificial chordae. Many of our repair patients left the operating room and hospital with moderate or severe tricuspid regurgitation. We have come 
to accept this rather than replacing the valve, which is associated with worse survival. Residual tricuspid regurgitation appeared to be stable over time.

Valvectomy without replacement, performed for 1 of our patients, requires normal lungs with low pulmonary vascular resistance and is advocated only in extreme cases (such as in patients with high risk of injection drug use relapse). These patients usually require subsequent valve replacement once the infection is cured. ${ }^{30}$ We do not believe that valvectomy or severe tricuspid regurgitation will be tolerated in patients with elevated pulmonary vascular resistance.

Survival in the setting of combined right-sided IE and invasive aortic + mitral IE is poor ${ }^{25}$ with reconstruction of the intervalvular fibrosa required. Techniques include the "commando" or "hemi-commando" procedure. ${ }^{31}$

\section{Mortality After Infective Endocarditis Surgery}

Reported surgical mortality for isolated right-sided IE in North America is 6\%, commensurate with our in-hospital mortality across the cohort, although outcomes are more favorable for isolated right-sided IE than right- and leftsided IE. ${ }^{1,32}$ Mitral valve involvement was associated with higher mortality, whereas aortic valve involvement was not, both findings consistent with our previous studies. ${ }^{25}$

Patients with chronic vascular access had the highest prevalence of peripheral arterial disease, which was associated with increased mortality; however, the most reliable risk factor for death was decreased renal function, predominantly, but not solely, found in patients with chronic vascular access. Although this group included most patients on dialysis, outcomes of IE surgery for patients on dialysis are still better than medical management. ${ }^{10}$ Tricuspid valve replacements were performed at similar rates across predisposing condition groups. The higher mortality in these patients may be explained by the burden of disease present at operation: Patients with extensive tricuspid valve destruction likely had extensive pulmonary emboli, persistent sepsis, and systemic effects of right heart failure. Although time from infection to surgery was not available, we believe earlier surgery in these patients may have limited disease progression, increased tricuspid valve repairs, and resulted in better outcomes.

\section{Infective Endocarditis Relapse/Recurrence}

Relapse of IE should be rare. Its most important risk factor is incomplete debridement of the valve ${ }^{13}$; removing the source of bacteremia is essential. Dental evaluation, appropriate drainage of abscesses, and other means of source control are important in preventing early relapse. Using medication-assisted treatment for injection drug users, placing epicardial pacemaker leads, and meticulous arteriovenous fistula cannulation hygiene during dialysis are examples of reinfection risk mitigation.
Recurrent IE was infrequent in our cohort, with most occurrences in injection drug users. Although neither history of IE nor valve replacement at index operation was a significant risk factor for recurrence, limited sample size may have affected these findings. Prosthetic valves and injection drug use remain complementary risk factors; injection drug use leads to bacteremia, and prosthetic valves provide a better adhesion site for organisms than native valves. ${ }^{33}$ Injection drug users who underwent tricuspid valve replacement at index operation were those who had a prior prosthetic tricuspid valve or had such extensive native valve damage that the surgeon deemed replacement necessary. If seen today, some of these patients may have had their native valves reconstructed instead of replaced. Nonetheless, based on experience with mitral valve reconstructions for IE, infection resistance and durability of valve reconstruction need further study.

Given that $87 \%$ of our patients, including $76 \%$ of injection drug users, did not develop recurrent IE during followup, risks of recurrence or reoperation are important, but should not impede a potentially life-saving operation.

\section{Study Strengths and Limitations}

Although one of the largest surgical series of right-sided IE, it represents a single, quaternary-care referral center more likely to receive patients with advanced and complex disease. The cohort included only patients selected for operation and thus by design was biased toward those with severe IE deemed to require surgery and healthy enough to tolerate it. Surgeons and IE care teams perform a large volume of IE operations annually, and results may not be generalizable.

Medically treated patients were not investigated in the present study. The majority of our IE patients are referrals for surgery, but many are deemed not to require an operation or to be too sick to have one. Therefore, we limited our study to surgically managed right-sided IE.

\section{CONCLUSIONS}

Patients undergoing operation for right-sided IE demonstrate substantial variability based on predisposing conditions and comorbid risk factors, but have tolerable short- and long-term mortality and low risk for relapse/ recurrence. Patient-specific factors, such as poor renal function and mitral valve IE, increased the risk of mortality, but predisposing condition did not. Tricuspid valve replacement was a risk factor for late mortality and should be avoided when possible. An individualized approach to patient selection and early operations in those with rightsided IE may improve patient outcomes.

\section{Conflict of Interest Statement}

Authors have nothing to disclose with regard to commercial support. 


\section{References}

1. Musci M, Siniawski H, Pasic M, Grauhan O, Weng Y, Meyer R, et al. Surgical treatment of right-sided active infective endocarditis with or without involvement of the left heart: 20-year single center experience. Eur J Cardiothorac Surg. 2007;32:118-25.

2. Cabell CH, Abrutyn E, Fowler VG Jr, Hoen B, Miro JM, Corey GR, et al. Use of surgery in patients with native valve infective endocarditis: results from the International Collaboration on Endocarditis Merged Database. Am Heart J. 2005;150: 1092-8.

3. Murdoch DR, Corey GR, Hoen B, Miro JM, Fowler VG Jr, Bayer AS, et al. Clinical presentation, etiology, and outcome of infective endocarditis in the 21st century: the International Collaboration on Endocarditis-Prospective Cohort Study. Arch Intern Med. 2009; 169:463-73.

4. Miro JM, del Rio A, Mestres CA. Infective endocarditis and cardiac surgery in intravenous drug abusers and HIV-1 infected patients. Cardiol Clin. 2003;21: 167-84. v-vi.

5. Gaca JG, Sheng S, Daneshmand MA, O’Brien S, Rankin JS, Brennan JM, et al. Outcomes for endocarditis surgery in North America: a simplified risk scoring system. J Thorac Cardiovasc Surg. 2011;141:98-106.e1-2.

6. Moreira D, Correia E, Rodrigues B, Santos L, Capelo J, Abreu L, et al. Isolated pulmonary valve endocarditis in a normal heart. Rev Port Cardiol. 2012;31:615-7.

7. Moss R, Munt B. Injection drug use and right sided endocarditis. Heart. 2003;89: 577-81.

8. Nadji G, Remadi JP, Coviaux F, Mirode AA, Brahim A, Enriquez-Sarano M, et al. Comparison of clinical and morphological characteristics of Staphylococcus aureus endocarditis with endocarditis caused by other pathogens. Heart. 2005; 91:932-7.

9. Shrestha NK, Jue J, Hussain ST, Jerry JM, Pettersson GB, Menon V, et al. Injection drug use and outcomes after surgical intervention for infective endocarditis. Ann Thorac Surg. 2015;100:875-82.

10. Raza S, Hussain ST, Rajeswaran J, Ansari A, Trezzi M, Arafat A, et al. Value of surgery for infective endocarditis in dialysis patients. J Thorac Cardiovasc Surg. 2017; 154:61-70.e6.

11. Thalme A, Westling K, Julander I. In-hospital and long-term mortality in infective endocarditis in injecting drug users compared to non-drug users: a retrospective study of 192 episodes. Scand J Infect Dis. 2007;39:197-204.

12. Li JS, Sexton DJ, Mick N, Nettles R, Fowler VG Jr, Ryan T, et al. Proposed modifications to the Duke criteria for the diagnosis of infective endocarditis. Clin Infect Dis. 2000;30:633-8.

13. Pettersson GB, Hussain ST, Shrestha NK, Gordon S, Fraser TG, Ibrahim KS, et al. Infective endocarditis: an atlas of disease progression for describing, staging, coding, and understanding the pathology. J Thorac Cardiovasc Surg. 2014; 147:1142-9.e2.

14. Nishimura RA, Otto CM, Bonow RO, Carabello BA, Erwin JP III, Guyton RA, et al. 2014 AHA/ACC guideline for the management of patients with valvular heart disease: executive summary: a report of the American College of Cardiology/American Heart Association task force on practice guidelines. Circulation. 2014;129:2440-92.

15. Habib G, Lancellotti P, Antunes MJ, Bongiorni MG, Casalta JP, Del Zotti F, et al. 2015 ESC guidelines for the management of infective endocarditis: The task force for the management of infective endocarditis of the European Society of Cardiology (ESC). Endorsed by: European Association for Cardio-Thoracic Surgery (EACTS), the European Association of Nuclear Medicine (EANM). Eur Heart J. 2015;36:3075-128

16. Pettersson GB, Coselli JS, Hussain ST, Griffin B, Blackstone EH, Gordon SM, et al. 2016 American Association for Thoracic Surgery (AATS) consensus guidelines: surgical treatment of infective endocarditis. Executive summary J Thorac Cardiovasc Surg. 2017;153:1241-58.e29.

17. Society of Thoracic Surgeons National Database. Available at: http://www.sts org/registries-research-center/sts-national-database/adult-cardiac-surgery-database/ data-collection. Accessed December 21, 2017.

18. Andersen PK, Borgan O, Gill RD, Kelding N. Statistical Models Based on Counting Processes. Chapter 4. Nonparametric Estimation. New York: Springer-Verlag; 1993.

19. Blackstone EH, Naftel DC, Turner ME Jr. The decomposition of time-varying hazard into phases, each incorporating a separate stream of concomitant information. J Am Stat Assoc. 1986;81:615-24.

20. Rajeswaran J, Blackstone EH. Identifying risk factors: challenges of separating signal from noise. J Thorac Cardiovasc Surg. 2017;153:1136-8.

21. Breiman L. Bagging predictors. Machine Learning. 1996;24:123-40.

22. Lipari RN, Hughes A. Trends in heroin use in the United States: 2002 to 2013 Substance Abuse and Mental Health Services Administration. Available at http://www.samhsa.gov/data/sites/default/files/report_1943/ShortReport-1943. html. Accessed February 27, 2017.

23. Sridhar AR, Lavu M, Yarlagadda V, Reddy M, Gunda S, Afzal R, et al. Cardiac implantable electronic device-related infection and extraction trends in the U.S Pacing Clin Electrophysiol. 2017;40:286-93.

24. Hussain ST, Shrestha NK, Witten J, Gordon SM, Houghtaling PL, Tingleff J, et al. Rarity of invasiveness in right-sided infective endocarditis. J Thorac Cardiovasc Surg. 2018;155:54-61.e1.

25. Hussain ST, Shrestha NK, Gordon SM, Houghtaling PL, Blackstone EH, Pettersson GB. Residual patient, anatomic, and surgical obstacles in treating active left-sided infective endocarditis. J Thorac Cardiovasc Surg. 2014;148 981-8.e4.

26. van Hal SJ, Jensen SO, Vaska VL, Espedido BA, Paterson DL, Gosbell IB. Predictors of mortality in Staphylococcus aureus bacteremia. Clin Microbiol Rev. 2012;25:362-86

27. Sohail MR, Uslan DZ, Khan AH, Friedman PA, Hayes DL, Wilson WR, et al Infective endocarditis complicating permanent pacemaker and implantable cardioverter-defibrillator infection. Mayo Clin Proc. 2008;83:46-53.

28. Gottardi R, Bialy J, Devyatko E, Tschernich H, Czerny M, Wolner E, et al. Midterm follow-up of tricuspid valve reconstruction due to active infective endocarditis. Ann Thorac Surg. 2007;84:1943-8.

29. Jiang SL, Li BJ, Zhang T, Ren CL, Wang Y, Chen TT, et al. Surgical treatment of isolated right-sided infective endocarditis. Tex Heart Inst J. 2011;38:639-42.

30. Arbulu A, Holmes RJ, Asfaw I. Surgical treatment of intractable right-sided infective endocarditis in drug addicts: 25 years experience. $J$ Heart Valve Dis. 1993;2:129-37; discussion 38-9.

31. Elgharably H, Hakim AH, Unai S, Hussain ST, Shrestha NK, Gordon S, et al. The incorporated aortomitral homograft for double-valve endocarditis: the "hemiCommando" procedure. Early and mid-term outcomes. Eur J Cardiothorac Surg. 2018;53:1055-61.

32. Carozza A, De Santo LS, Romano G, Della Corte A, Ursomando F, Scardone M, et al. Infective endocarditis in intravenous drug abusers: patterns of presentation and long-term outcomes of surgical treatment. J Heart Valve Dis. 2006;15: 125-31.

33. Limoli DH, Jones CJ, Wozniak DJ. Bacterial extracellular polysaccharides in biofilm formation and function. Microbiol Spectr. 2015;3.

Key Words: infective endocarditis, right-sided, tricuspid valve, pulmonary valve, etiology 


\section{APPENDIX E1. VARIABLES CONSIDERED IN THE MULTIVARIABLE ANALYSES \\ Endocarditis Details}

Valves affected (tricuspid, pulmonary, mitral, aortic, right side only), prosthetic or native valve, invasive disease, organism.

\section{Predisposing Condition}

Injection drug use, cardiac implantable device, chronic vascular access, other/none.

\section{Persuasive Clinical Findings}

Severe valvular regurgitation, right heart failure, left heart failure, septic emboli, large vegetations, medical failure/uncontrolled infection, valve destruction/damage, prosthetic valve dehiscence, fistula/abscess/pseudoaneurysm, patent foramen ovale/atrial septal defect/ventricular septal defect, worsening heart block/conduction defect.

\section{Microorganism}

Staphylococcus aureus, coagulase-negative staphylococcus, enterococcus, viridans group streptococcus, grampositive cocci not further identified, polymicrobial, fungus, pathogen not identified, other.

\section{Demographics}

Age (y), sex, race (black, white, other), height $(\mathrm{cm})$, weight $(\mathrm{kg})$, body surface area $\left(\mathrm{m}^{2}\right)$, body mass index $\left(\mathrm{kg} / \mathrm{m}^{2}\right)$.

\section{Clinical Status}

New York Heart Association functional class (I-IV), emergency operation.

\section{Preoperative Echocardiographic Findings}

Aortic valve regurgitation grade, mitral valve regurgitation grade, tricuspid valve regurgitation grade, aortic valve stenosis, mitral valve stenosis, tricuspid valve stenosis, left ventricular (LV) ejection fraction ( $\%), \mathrm{LV}$ inner diastolic diameter $(\mathrm{cm})$, LV inner systolic diameter $(\mathrm{cm})$, right ventricular systolic pressure $(\mathrm{mmHg})$, left atrial diameter $(\mathrm{cm})$, posterior wall thickness $(\mathrm{cm})$.

\section{Cardiac Comorbidity}

Preoperative atrial fibrillation, number of prior cardiac operations, heart failure, complete heart block, prior myocardial infarction.

\section{Noncardiac Comorbidity}

Prior stroke, pharmacologically treated diabetes (insulin and noninsulin dependent), history of hypertension, peripheral arterial disease, history of smoking, chronic obstructive pulmonary disease, renal failure requiring dialysis, blood urea nitrogen $(\mathrm{mg} / \mathrm{dL})$, creatinine $(\mathrm{mg} / \mathrm{dL})$, creatinine clearance $(\mathrm{mL} / \mathrm{min})$, glomerular filtration rate $(\mathrm{mL} / \mathrm{min} /$ $1.73 \mathrm{~m}^{2}$ ), bilirubin (mg/dL), cholesterol (total, highdensity lipoprotein, low-density lipoprotein), triglycerides $(\mathrm{mg} / \mathrm{dL})$, hematocrit $(\%)$.

\section{Surgical Procedure}

Concomitant coronary artery bypass grafting, concomitant aortic surgery, tricuspid valve replacement, tricuspid valve repair/reconstruction.

\section{Experience}

Date of operation (days from January 1, 2002, to index operation). 


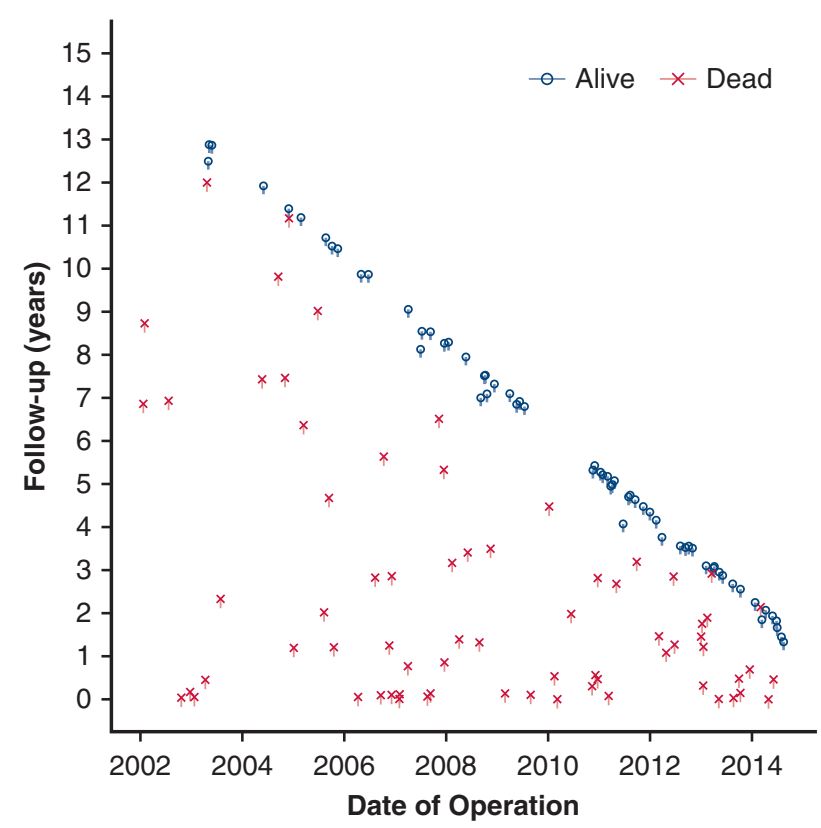

FIGURE E1. Chronogram of follow-up of patients undergoing surgery for right-sided IE. Red x's denote deaths, and blue circles denote patients alive at follow-up.

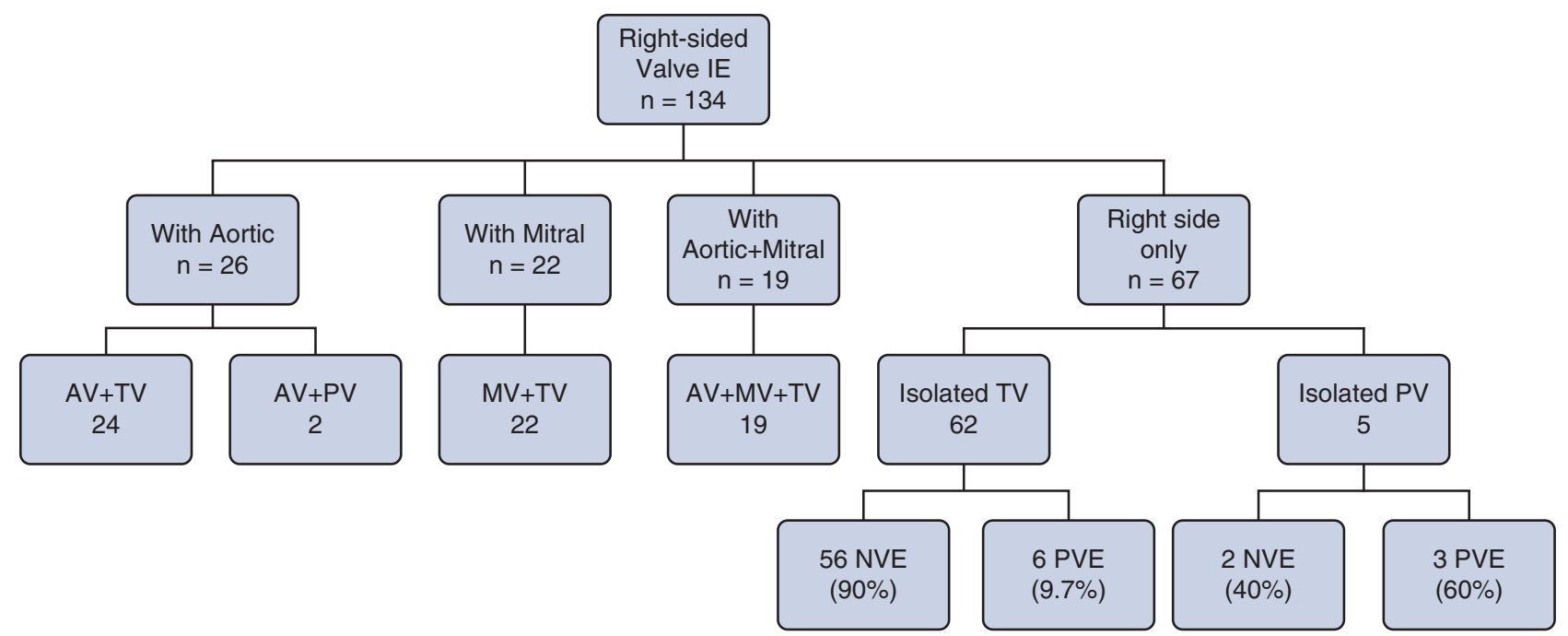

FIGURE E2. CONSORT-style diagram of study cohort. $I E$, Infective endocarditis; $A V$, aortic valve; $T V$, tricuspid valve; $P V$, pulmonary valve; $M V$, mitral valve; $N V E$, native valve endocarditis; $P V E$, prosthetic valve endocarditis. 


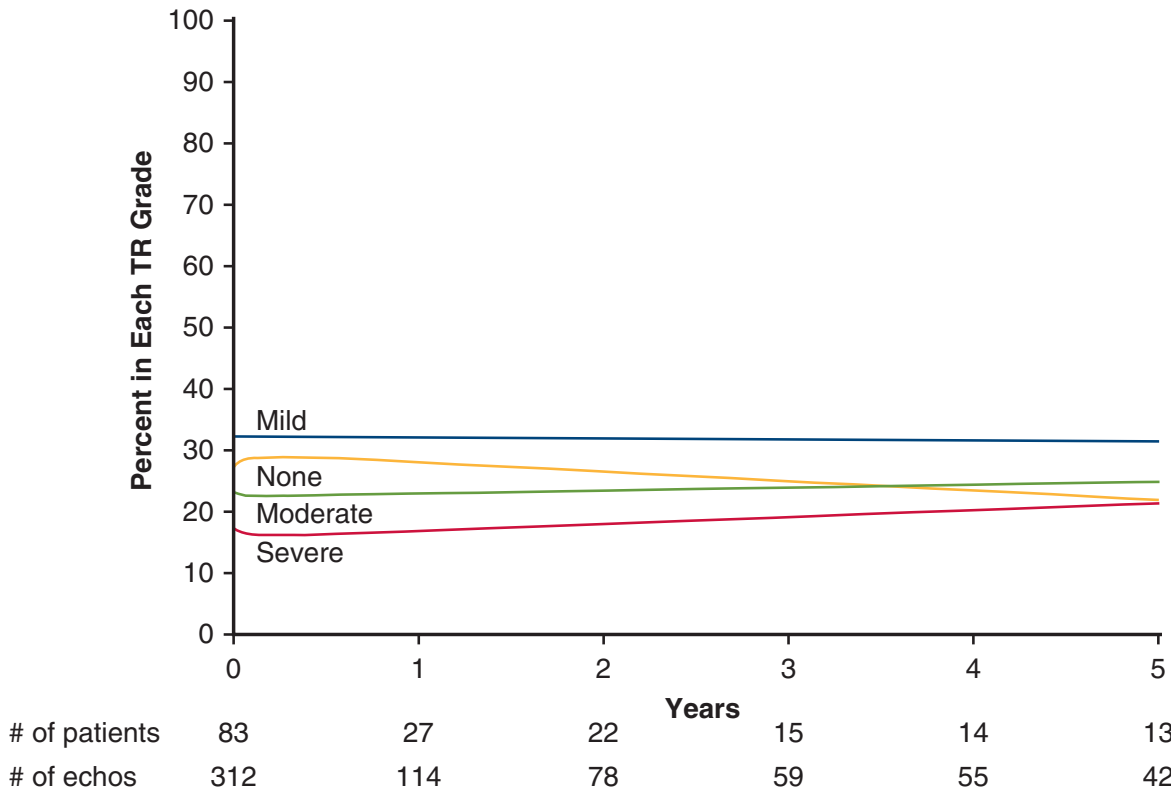

FIGURE E3. Postoperative tricuspid regurgitation $(T R)$ in those receiving tricuspid repair/reconstruction for right-sided IE. Lines depict prevalence of TR in each grade based on a linear mixed model. Yellow line is no TR, blue line is mild TR, green line is moderate TR, and red line is severe TR. 


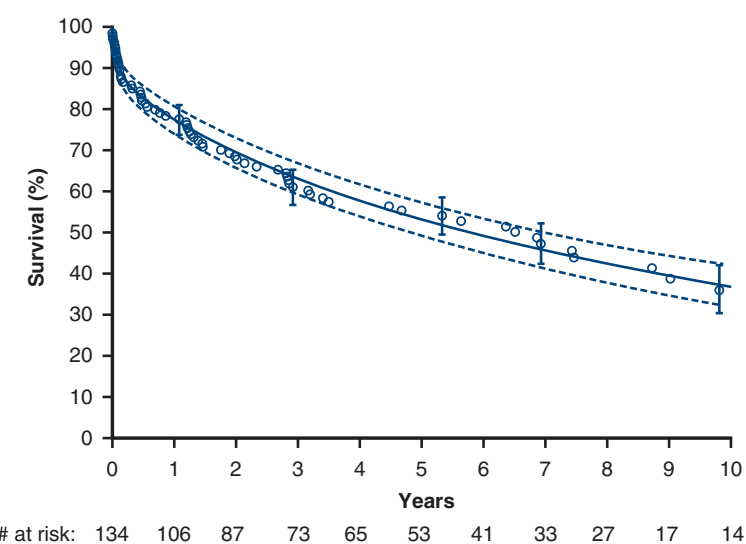

A
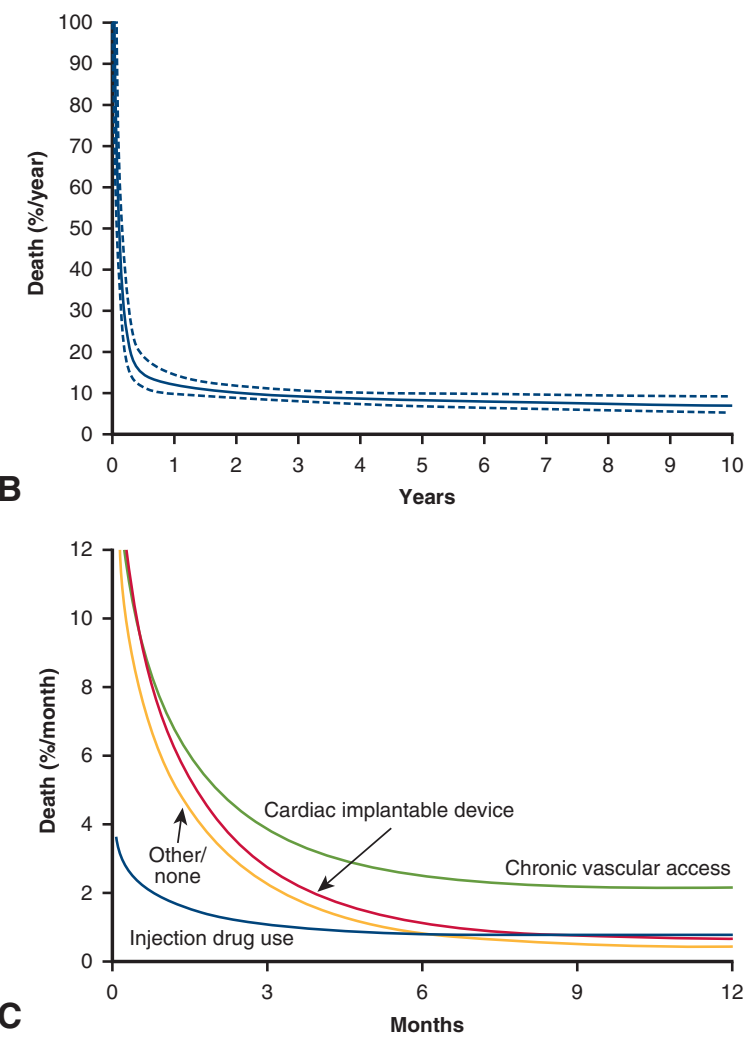

FIGURE E4. Survival after surgery for right-sided IE. A, Solid line is parametric estimate enclosed within a $68 \%$ dashed confidence band equivalent to \pm 1 standard error, each circle represents a death, and vertical bars represent $68 \%$ confidence limits of Kaplan-Meier estimates. B, Hazard function for death. Solid line is parametric estimate enclosed within a $68 \%$ dashed confidence band equivalent to \pm 1 standard error. C, Hazard function for death within first 12 months according to predisposing condition. Injection drug use group is denoted by blue line, cardiac implantable device group is denoted by red line, chronic vascular access group is denoted by green line, and other/none group is denoted by yellow line. 


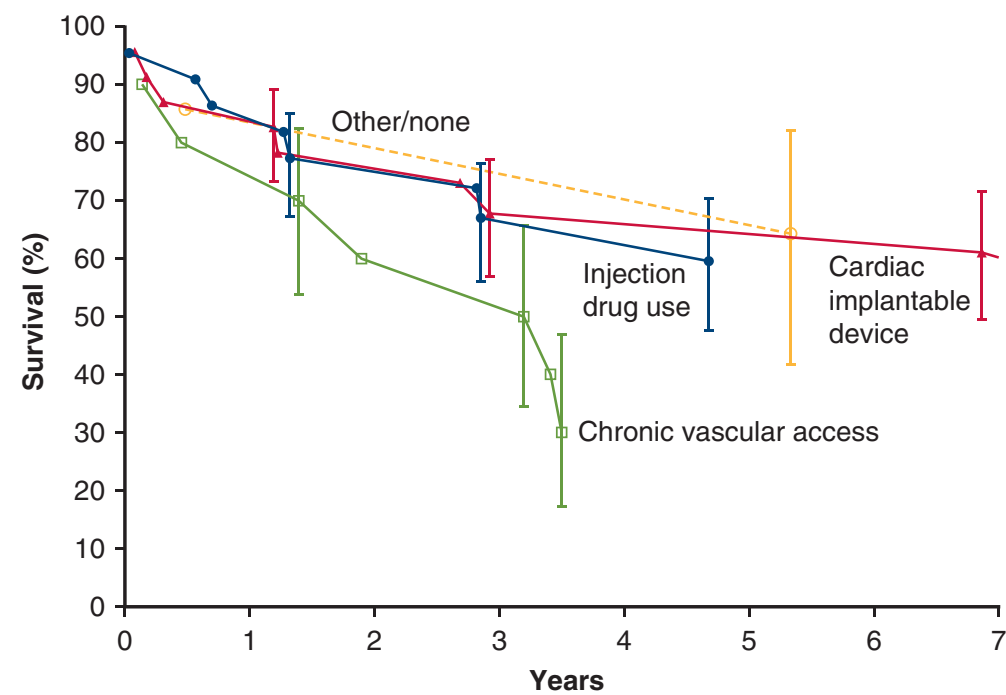

$\begin{array}{lrrrrrrrr}\text { \# at risk } & & & & & & & & \\ \text { Drug use } & 22 & 20 & 17 & 14 & 1 & 7 & 6 & 6 \\ \text { CID } & 23 & 21 & 28 & 14 & 14 & 12 & 11 & 9 \\ \text { Vasc. access } & 10 & 9 & 7 & 7 & - & - & - & - \\ \text { Other/none } & 7 & 6 & 6 & 6 & 5 & 5 & 4 & 3\end{array}$

A

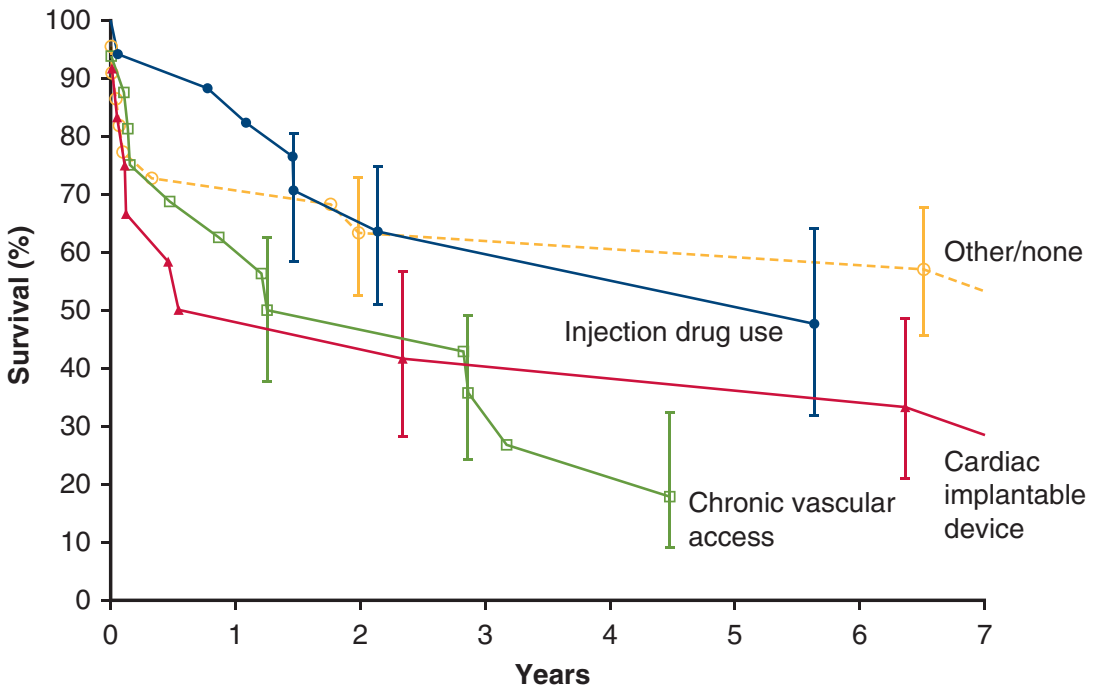

$\begin{array}{lrrrrrrrr}\text { \# at risk } & & & & & & & & \\ \text { Drug use } & 17 & 16 & 11 & 9 & 9 & 6 & 4 & 2 \\ \text { CID } & 12 & 7 & 6 & 6 & 6 & 6 & 5 & 5 \\ \text { Vasc. access } & 16 & 11 & 8 & 5 & 4 & 3 & 2 & 1 \\ \text { Other/none } & 22 & 17 & 14 & 13 & 12 & 12 & 11 & 10\end{array}$

B

FIGURE E5. Survival of patients undergoing surgery for right-sided IE according to predisposing condition. Each symbol represents a death and vertical bars $68 \%$ confidence limits equivalent to \pm 1 standard error. Injection drug use is denoted by blue lines and filled circles, CID is denoted by red lines and triangles, chronic vascular access is denoted by green lines and squares, and other/none is denoted by yellow dashed lines and open circles. A, Isolated tricuspid valve IE. B, Right- and left-sided IE. CID, Cardiac implantable device. 


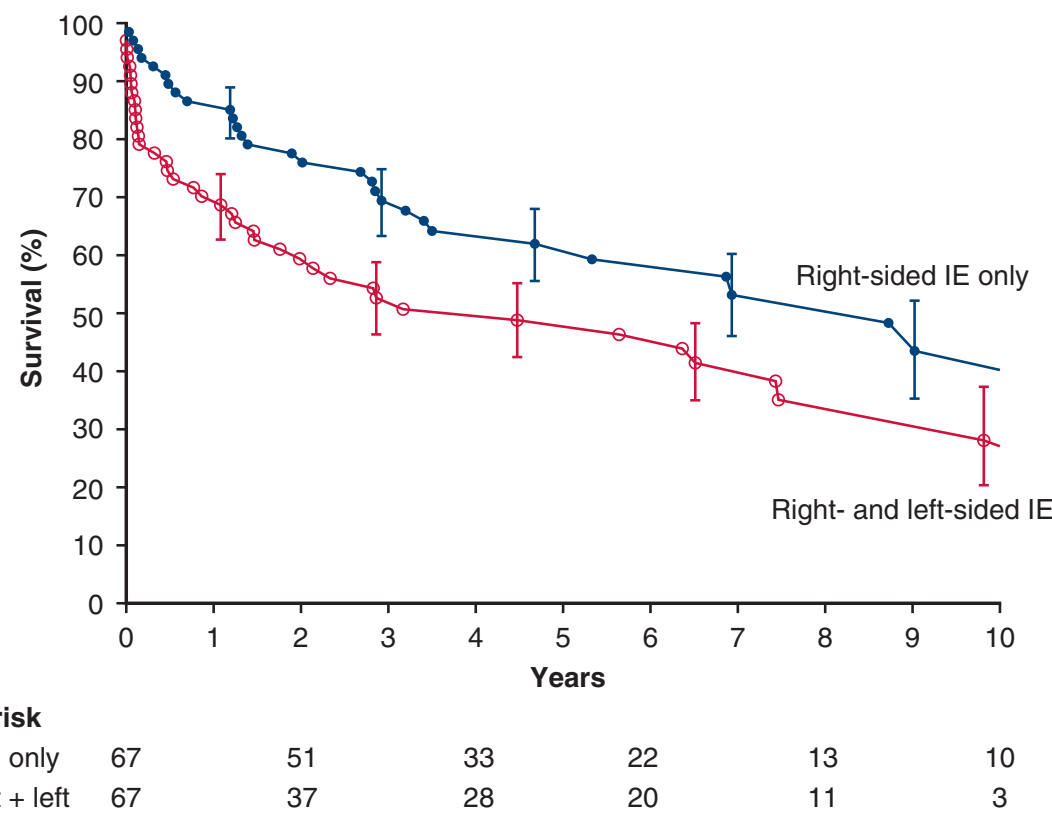

FIGURE E6. Survival after surgery for right-sided and right- and left-sided IE. Format is as in Figure E4. Right-sided IE-only group is denoted by blue line and filled circles, and right- and left-sided IE group by red line and open circles. IE, Infective endocarditis; RSIE, right-sided IE.

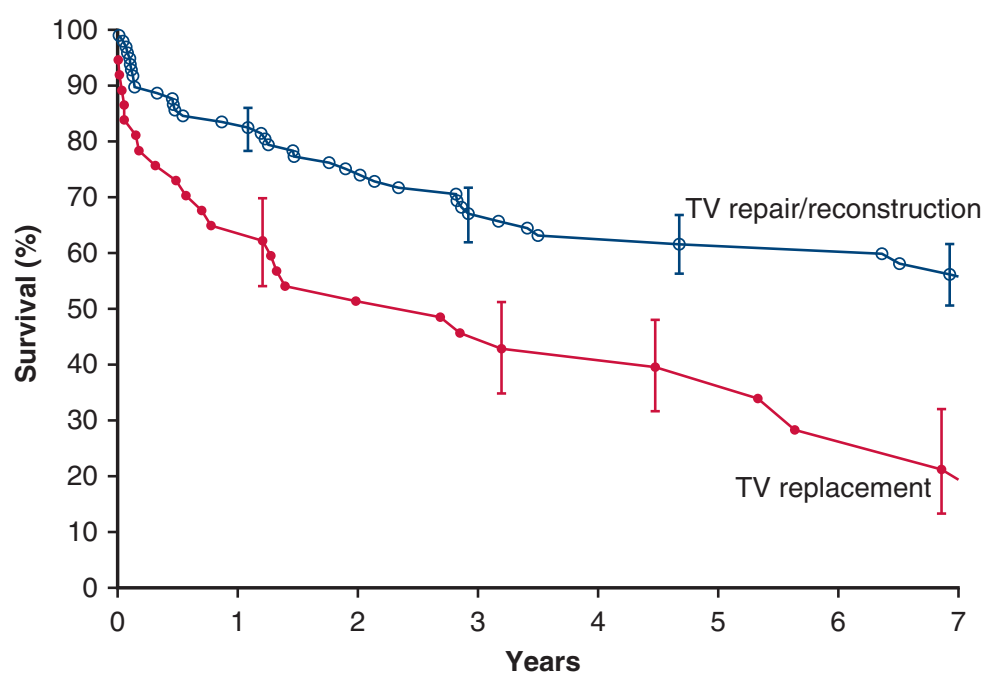

\# at risk

$\begin{array}{lllllllll}\text { Repair/reconstruct. } & 93 & 82 & 69 & 52 & 50 & 42 & 42 & 30\end{array}$

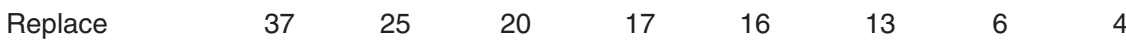

FIGURE E7. Survival after tricuspid valve (TV) repair/reconstruction or replacement in entire cohort. Format is as in Figure E4. TV repair/reconstruction is denoted by blue line and open circles, and TV replacement by red line and filled circles. 


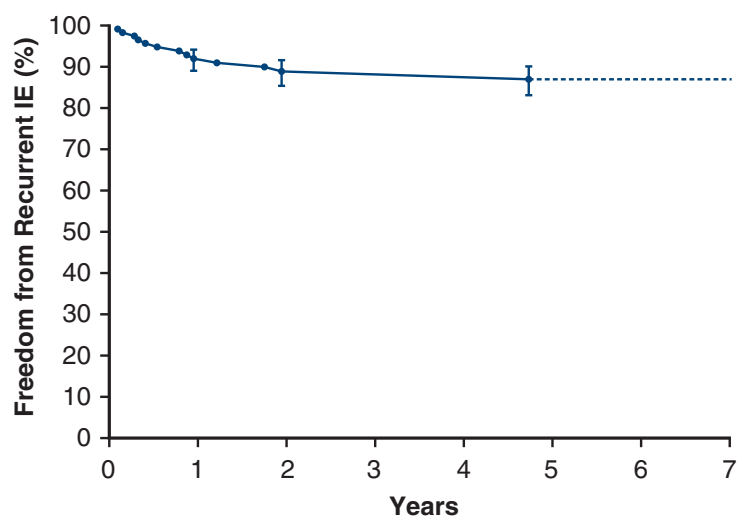

$\begin{array}{lllllllll}\text { \# at risk } & 134 & 99 & 82 & 68 & 56 & 46 & 41 & 33\end{array}$

FIGURE E8. Freedom from relapse/recurrent IE after surgery for right-sided IE in overall cohort. Format is as in Figure E4. IE, Infective endocarditis.

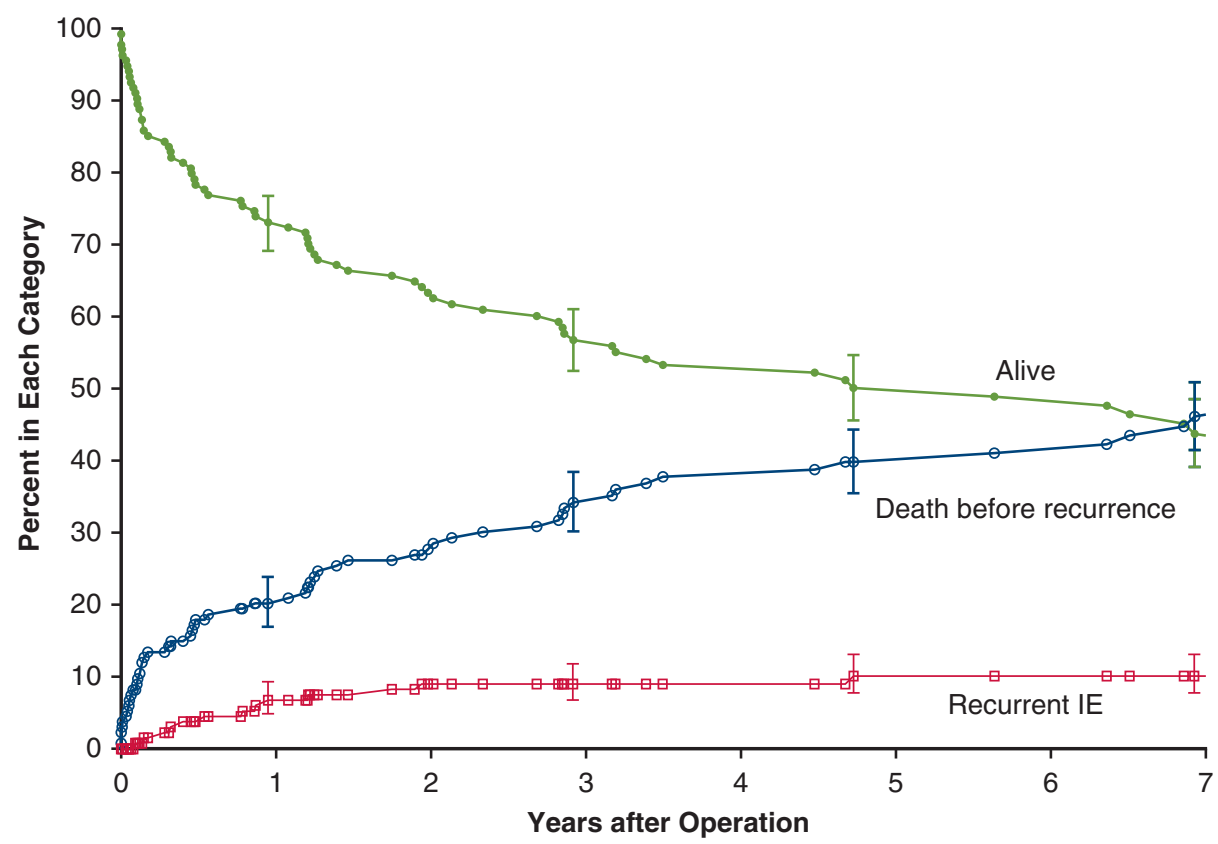

FIGURE E9. Competing risks of death and relapse/recurrent endocarditis after surgery for right-sided IE. Format is as in Figure E4. IE, Infective endocarditis. 


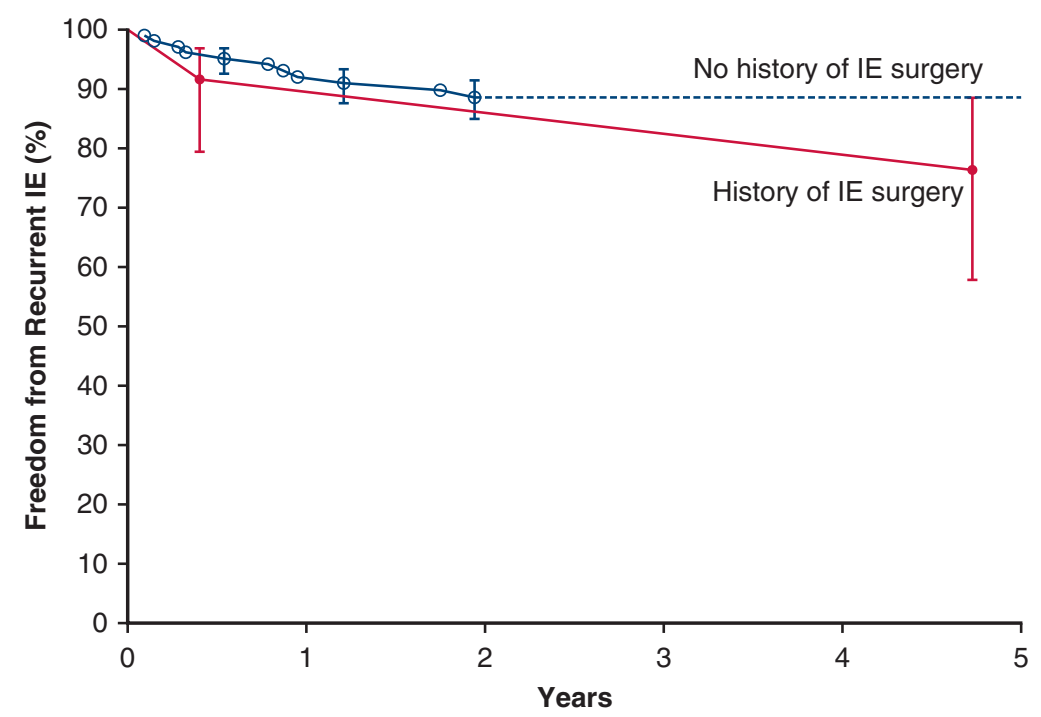

\section{\# at risk}

History of IE surgery

$\begin{array}{lc}\text { No } & 120 \\ \text { Yes } & 14\end{array}$

89
11

74

62

50

41

14

9

7

7

6

FIGURE E10. Freedom from relapse/recurrent IE stratified by history of IE surgery at index operation. Format is as in Figure E4. History of IE surgery is denoted by red line and filled circles, and no history of IE surgery by blue line and open circles. IE, Infective endocarditis. 


\begin{tabular}{|c|c|c|c|c|c|c|c|c|c|c|}
\hline \multirow{2}{*}{$\begin{array}{l}\text { Patient } \\
\text { No. }\end{array}$} & \multicolumn{4}{|c|}{ If valve infected, what type of valve? } & \multirow{2}{*}{$\begin{array}{l}\text { Invasion from } \\
\text { left to right* }\end{array}$} & \multirow[b]{2}{*}{ Index procedures } & \multirow{2}{*}{$\begin{array}{l}\text { Prior surgery for } \\
\text { congenital heart } \\
\text { anomaly }\end{array}$} & \multirow{2}{*}{$\begin{array}{l}\text { History of } \\
\text { IE }\end{array}$} & \multirow[b]{2}{*}{ Microbiology } & \multirow[b]{2}{*}{ Other risk factors for IE } \\
\hline & Tricuspid & Pulmonary & Mitral & Aortic & & & & & & \\
\hline 1 & Native & - & - & - & - & $\mathrm{TVr}$ & No & No & CoNS & - \\
\hline 2 & - & Native & - & Native & No & AVR, PVr, VSD closure & No & No & $S$ bovis & Surgical site infections, VSD \\
\hline 3 & Native & - & - & - & - & $\mathrm{TVr}$ & No & No & $S$ aureus & $\begin{array}{l}\text { Lower leg abscess s/p } \\
\text { amputation }\end{array}$ \\
\hline 4 & Native & - & Native & Native & No & AVR, MVR, TVr & No & No & A defectiva & Recent medical procedures \\
\hline 5 & - & Allo & - & Auto & No & Allo PVR, AVr, TVr & Yes: Ross procedure & No & $S$ aureus & - \\
\hline 6 & Native & - & - & Native & No & AVR, TVr & No & No & E faecalis & Recent vascular surgery \\
\hline 7 & Native & - & - & Prosth & Yes & Allo AVR, TVr & No & No & Efaecalis & Recent medical procedures \\
\hline 8 & Native & - & Native & - & No & MVr, TVr, VSD closure & No & No & S pyogenes & Unrepaired VSD \\
\hline 9 & Native & - & Native & Prosth & Yes & Allo AVR, TVr, MVr & No & No & $S$ aureus & - \\
\hline 10 & Native & - & Prosth & - & No & MVR, TVr & No & No & CoNS & Recent abdominal surgery \\
\hline 11 & Native & - & - & Native & No & AVR, TVr, VSD closure & No & No & CoNS & Unrepaired VSD \\
\hline 12 & - & Allo & - & - & - & Allo PVR & No & Yes & PNID & $\begin{array}{l}\text { Previous Ross procedure for } \\
\text { AV IE }\end{array}$ \\
\hline 13 & Native & - & - & Native & No & AVR, TVr & No & No & $S$ aureus & $\begin{array}{l}\text { Lower leg abscess s/p } \\
\text { amputation }\end{array}$ \\
\hline 14 & - & Native & - & - & - & PVr, PFO closure & Yes: VSD repair & No & A xylosoxidans & Unrepaired PFO \\
\hline 15 & Native & - & Native & Native & No & AVR, TVR, MVr & No & No & $S$ pneumoniae & - \\
\hline 16 & Native & - & Native & Native & Yes & Allo AVR, MVR, TVr & No & No & $B$ henslae & Aortic stenosis \\
\hline 17 & Native & - & - & Native & No & Allo AVR, TVr & No & No & $S$ aureus & - \\
\hline 18 & Native & - & - & Native & No & AVR, TVr & No & No & PNID & Septic miscarriage \\
\hline 19 & - & Native & - & - & - & Allo PVR & No & No & CoNS & $\begin{array}{l}\text { Penetrating sternal wire in } \\
\text { RVOT }\end{array}$ \\
\hline 20 & - & Prosth & - & - & - & Allo PVR & $\begin{array}{l}\text { Tetralogy of Fallot; } \\
\text { RVOT conduit, } \\
\text { LVOT repair }\end{array}$ & No & CoNS & - \\
\hline 21 & Prosth & - & - & - & - & TVR & No & $\begin{array}{l}\text { Yes: TVR } \\
\quad \text { for IE }\end{array}$ & $S$ aureus & Recent gynecologic surgery \\
\hline 22 & Native & - & Native & Native & Yes & AVR, MVR, TVR & No & No & CoNS & - \\
\hline 23 & Native & - & Native & Prosth & Yes & Allo AVR, TVr, MVr & No & No & $S$ aureus & - \\
\hline 24 & Native & - & - & - & - & TVr, PFO, and VSD closure & No & No & PNID & Unrepaired VSD, PFO \\
\hline 25 & Native & - & - & - & - & TVR & No & No & $P$ vulgaris & Gangrenous cholecystitis \\
\hline 26 & Native & - & - & - & - & $\mathrm{TVr}$, ASD closure & No & No & CoNS & Unrepaired ASD \\
\hline
\end{tabular}


TABLE E1. Continued

\begin{tabular}{|c|c|c|c|c|c|c|c|c|c|c|}
\hline \multirow{2}{*}{$\begin{array}{l}\text { Patient } \\
\text { No. }\end{array}$} & \multicolumn{4}{|c|}{ If valve infected, what type of valve? } & \multirow{2}{*}{$\begin{array}{l}\text { Invasion from } \\
\text { left to right* }\end{array}$} & \multirow[b]{2}{*}{ Index procedures } & \multirow{2}{*}{$\begin{array}{l}\text { Prior surgery for } \\
\text { congenital heart } \\
\text { anomaly }\end{array}$} & \multirow{2}{*}{$\begin{array}{l}\text { History of } \\
\text { IE }\end{array}$} & \multirow[b]{2}{*}{ Microbiology } & \multirow[b]{2}{*}{ Other risk factors for IE } \\
\hline & Tricuspid & Pulmonary & Mitral & Aortic & & & & & & \\
\hline 27 & Native & - & - & Prosth & Yes & Allo AVR, TVr & No & No & VGS & $\begin{array}{l}\text { AVR, hemi-arch replacement } \\
\text { for ascending aortic }\end{array}$ \\
\hline
\end{tabular}

\begin{tabular}{|c|c|c|c|c|c|c|c|c|c|c|}
\hline 28 & Native & - & - & Native & No & AVR, TVR & No & No & C hominis & - \\
\hline 29 & Native & - & Native & Native & No & AVR, MVR, TVr & No & No & E faecalis & Immunosuppression \\
\hline 30 & Native & - & - & - & - & $\mathrm{TV}$, $\mathrm{PFO}$ closure & No & No & $S$ aureus & Unrepaired PFO \\
\hline 31 & Native & - & - & Native & No & Allo AVR, TVr, VSD closure & No & No & $S$ pneumoniae & Unrepaired repaired VSD \\
\hline 32 & Pros & - & Prosth & Prosth & Yes & Allo AVR, MVR, TVR & No & No & PNID & $\begin{array}{l}\text { Triple valve replacement for } \\
\text { Libman-Sacks endocarditis }\end{array}$ \\
\hline 33 & Native & - & Native & Prosth & Yes & Allo AVR, MVr, TVr & No & No & CoNS & - \\
\hline
\end{tabular}

$A V R$, Aortic valve replacement; $P V r$, pulmonary valve repair; $V S D$, ventricular septal defect; $A l l o$, allograft; $A u t o$, autograft; $P V R$, pulmonary valve replacement; $A V r$, aortic valve repair; $T V r$, tricuspid valve repair; $P N I D$, pathogen not
identified; $I E$, infective endocarditis; $P F O$, patent foramen ovale; $C o N S$, coagulase-negative staphylococcus; $R V O T$, right ventricular outflow tract; $P$ rosth, prosthetic; $L V O T$, left ventricular outflow tract; $P V$, pulmonary valve; $V G S$, viridans group streptococcus. *Evidence of invasive fistula tract from a left-sided infection to right-sided valves.

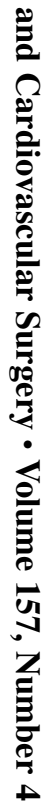


TABLE E2. Characteristics of patients undergoing surgery for pulmonary valve infective endocarditis

Patient If valve infected, what type of valve? Predisposing

condition

Index procedures

Prior surgery for congenital

No. Tricuspid Pulmonary Mitral Aortic

Other/none

AVR, PVr, VSD closure

heart anomaly

History of IE Microbiology

Other risk factors for IE

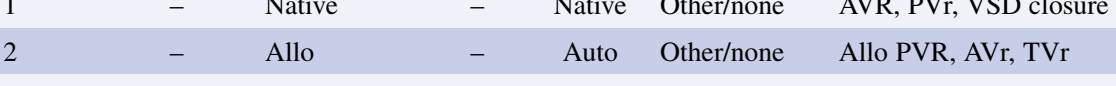

No

No $\quad S$ bovis

Surgical site infections, VSD

Allo $\quad-\quad \quad-\quad$ Other/none

Allo PVR Ross procedure

No $\quad S$ aureus

$4+2$

$4 \quad-\quad$ Native $\quad-\quad \ldots \quad-\quad$ Other/none

PVr, PFO closure

No

Yes PNID

Previous Ross procedure for IE

$5 \quad-\quad$ Native

Other/none Allo PVR

VSD repair

No

\begin{tabular}{|c|c|c|c|c|c|c|c|c|c|c|}
\hline & & & & & & & & & \multicolumn{2}{|c|}{ RVOT } \\
\hline 6 & - & Prosth & - & - & Other/none & Allo PVR & $\begin{array}{l}\text { Tetralogy of Fallot; RVOT } \\
\text { conduit, LVOT repair }\end{array}$ & No & CoNS & - \\
\hline 7 & - & Allo & - & - & $\begin{array}{l}\text { Injection } \\
\text { drug use }\end{array}$ & Allo PVR & $\begin{array}{c}\text { Congenital PV stenosis: } \\
\text { allograft RVOT } \\
\text { replacement }\end{array}$ & No & VGS & - \\
\hline
\end{tabular}

$-\quad-\quad$ Other/none

\begin{tabular}{|c|c|c|c|c|c|c|c|c|c|c|}
\hline & & 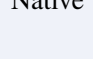 & & & 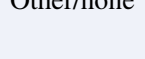 & 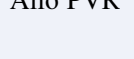 & & a & 年 & RVOT \\
\hline 6 & - & Prosth & - & - & Other/none & Allo PVR & $\begin{array}{c}\text { Tetralogy of Fallot; RVOT } \\
\text { conduit, LVOT repair }\end{array}$ & No & CoNS & - \\
\hline 7 & - & Allo & - & - & $\begin{array}{l}\text { Injection } \\
\text { drug use }\end{array}$ & Allo PVR & $\begin{array}{c}\text { Congenital PV stenosis: } \\
\text { allograft RVOT } \\
\text { replacement }\end{array}$ & No & VGS & - \\
\hline
\end{tabular}

No

A xylosoxidans Unrepaired PFO

$\overline{A V R \text {, Aortic valve replacement; } P V r \text {, pulmonary valve repair; } V S D \text {, ventricular septal defect; } A l l o \text {, allograft; } A u t o \text {, autograft; } P V R \text {, pulmonary valve replacement; } A V r \text {, aortic valve repair; } T V r \text {, tricuspid valve repair; } P N I D, \text { pathogen not }}$ identified; IE, infective endocarditis; $P F O$, patent foramen ovale; CoNS, coagulase-negative staphylococcus; RVOT, right ventricular outflow tract; Prosth, prosthetic; $L V O T$, left ventricular outflow tract; $P V$, pulmonary valve; VGS, viridans group streptococcus. 
TABLE E3. Characteristics of patients undergoing surgery for fungal right-sided infective endocarditis

\begin{tabular}{|c|c|c|c|c|c|c|c|c|c|}
\hline \multirow{2}{*}{$\begin{array}{c}\text { Patient } \\
\text { No. }\end{array}$} & \multicolumn{4}{|c|}{ If valve infected, what type of valve? } & \multirow{2}{*}{$\begin{array}{l}\text { Predisposing } \\
\text { condition }\end{array}$} & \multirow{2}{*}{$\begin{array}{c}\text { Index } \\
\text { procedures }\end{array}$} & \multirow[b]{2}{*}{ Microbiology } & \multirow{2}{*}{$\begin{array}{l}\text { Long-term } \\
\text { fungal } \\
\text { suppression }\end{array}$} & \multirow[b]{2}{*}{ Outcomes } \\
\hline & Tricuspid & Pulmonary & Mitral & Aortic & & & & & \\
\hline 1 & Native & - & - & - & Injection drug use & TVR & C albicans & Fluconazole & $\begin{array}{l}\text { Died without recurrence } \\
16 \text { mo after index } \\
\text { operation }\end{array}$ \\
\hline 2 & Prosth & - & - & - & Injection drug use & $\begin{array}{l}\text { TVR with } \\
\text { pulmonary } \\
\text { allograft }\end{array}$ & $\begin{array}{l}\text { C albicans, } \\
\text { P aeruginosa }\end{array}$ & None & $\begin{array}{l}\text { Alive without events } \\
56 \text { mo after index } \\
\text { operation }\end{array}$ \\
\hline 3 & Native & - & - & - & $\begin{array}{l}\text { Cardiac implantable } \\
\text { device }\end{array}$ & $\mathrm{TVr}$ & A flavus & Voriconazole & $\begin{array}{l}\text { Died without recurrence } \\
36 \text { mo after index } \\
\text { operation }\end{array}$ \\
\hline 4 & $\begin{array}{c}\text { Repaired } \\
\text { native }\end{array}$ & - & Prosth & - & $\begin{array}{l}\text { Chronic vascular } \\
\text { access }\end{array}$ & TVR & C tropicalis & None & $\begin{array}{l}\text { Alive without events } \\
42 \text { mo after index } \\
\text { operation }\end{array}$ \\
\hline
\end{tabular}

TVR, Tricuspid valve replacement; Prosth, prosthetic; $T V r$, tricuspid valve repair.

TABLE E4. Surgical and postoperative outcomes according to predisposing condition

\begin{tabular}{|c|c|c|c|c|c|}
\hline \multirow[b]{2}{*}{ Characteristics } & \multicolumn{4}{|c|}{ Predisposing condition } & \multirow[b]{2}{*}{$P$} \\
\hline & $\begin{array}{c}\text { Injection drug use } \\
(\mathrm{n}=40) \text { No. }(\%) \text { or } \\
\text { median }[15 \text { th, } 85 \text { th } \\
\text { percentiles] }\end{array}$ & $\begin{array}{c}\text { Cardiac implantable } \\
\text { device }(n=35) \\
\text { No. }(\%) \text { or median } \\
{[15 \text { th, } 85 \text { th percentiles }]}\end{array}$ & $\begin{array}{c}\text { Chronic vascular } \\
\text { access }(n=26) \text { No. }(\%) \\
\text { or median }[15 \text { th, } \\
\text { 85th percentiles }]\end{array}$ & $\begin{array}{l}\text { Miscellaneous }(n=33) \\
\text { No. }(\%) \text { or median } \\
\text { [15th, 85th percentiles] }\end{array}$ & \\
\hline \multicolumn{6}{|l|}{ Procedural } \\
\hline $\begin{array}{l}\text { Myocardial ischemic } \\
\text { time (min) }\end{array}$ & $79[29,138]$ & $90[6,175]$ & $102[42,162]$ & $110[44,192]$ & .14 \\
\hline $\begin{array}{l}\text { Cardiopulmonary bypass } \\
\text { time ( } \mathrm{min} \text { ) }\end{array}$ & $93[49,179]$ & $122[56,240]$ & $141[90,240]$ & $134[63,275]$ & .02 \\
\hline \multicolumn{6}{|l|}{ Blood products } \\
\hline \multicolumn{6}{|l|}{ Intraoperative* } \\
\hline Cryoprecipitate & $1(2.6)$ & $2(7.7)$ & $6(24)$ & $6(23)$ & .02 \\
\hline Fresh frozen plasma & $8(21)$ & $10(38)$ & $12(48)$ & $11(42)$ & .10 \\
\hline Platelets & $11(28)$ & $11(42)$ & $17(68)$ & $13(50)$ & .02 \\
\hline Red blood cells & $28(72)$ & $16(62)$ & $20(80)$ & $22(85)$ & .2 \\
\hline \multicolumn{6}{|l|}{ Postoperative } \\
\hline Cryoprecipitate & $3(7.5)$ & $1(2.9)$ & $3(12)$ & $3(9.1)$ & .6 \\
\hline Fresh frozen plasma & $7(18)$ & $6(17)$ & $5(19)$ & $7(21)$ & $>.9$ \\
\hline Platelets & $5(13)$ & $10(29)$ & $8(31)$ & $7(21)$ & .2 \\
\hline Red blood cells & $27(68)$ & $26(74)$ & $23(88)$ & $24(73)$ & .3 \\
\hline \multicolumn{6}{|l|}{ Postoperative complications } \\
\hline Hospital death & $0(0)$ & $2(5.7)$ & $2(7.7)$ & $4(12)$ & .18 \\
\hline Stroke & $0(0)$ & $0(0)$ & $0(0)$ & $2(6.1)$ & .10 \\
\hline $\begin{array}{l}\text { Reoperation for bleeding/ } \\
\text { tamponade }\end{array}$ & $3(7.5)$ & $3(8.6)$ & $1(3.8)$ & $4(12)$ & .7 \\
\hline $\begin{array}{l}\text { Other noncardiac } \\
\text { reoperation }\end{array}$ & $5(13)$ & $4(11)$ & $3(12)$ & $5(15)$ & $>.9$ \\
\hline Renal failure & $1(2.5)$ & $8(23)$ & $0(0)$ & $8(24)$ & .002 \\
\hline $\begin{array}{l}\text { Prolonged ventilation } \\
\qquad(>24 \mathrm{~h})\end{array}$ & $11(28)$ & $16(46)$ & $12(46)$ & $12(36)$ & .3 \\
\hline \multicolumn{6}{|l|}{ Length of stay } \\
\hline ICU (h) & $84[25,208]$ & $100[42,413]$ & $135[40,690]$ & $72[24,284]$ & .08 \\
\hline Postoperative (d) & $14[7.1,27]$ & $13[8.0,28]$ & $17[6.2,40]$ & $11[6.3,17]$ & .15 \\
\hline Hospital (d) & $25[13,34]$ & $22[14,46]$ & $25[12,54]$ & $19[12,30]$ & .04 \\
\hline
\end{tabular}

ICU, Intensive care unit. *Intraoperative blood data incomplete; available in $39,25,26$, and 26 patients, respectively. 
TABLE E5. New heart block after surgery for right-sided infective endocarditis

\begin{tabular}{|c|c|c|c|c|c|c|c|}
\hline Patient No. & Valves affected & $\begin{array}{c}\text { Type of valves } \\
\text { affected }\end{array}$ & $\begin{array}{l}\text { Predisposing } \\
\text { condition }\end{array}$ & $\begin{array}{c}\text { Index } \\
\text { procedures }\end{array}$ & Preoperative ECG & $\begin{array}{c}\text { Postoperative } \\
\text { ECG }\end{array}$ & $\begin{array}{c}\text { PPM } \\
\text { placed? }\end{array}$ \\
\hline \multicolumn{8}{|c|}{ Isolated right-sided IE } \\
\hline 1 & TV & Native & Injection drug use & TVR & ST & $\begin{array}{c}\text { First-degree } \\
\text { block }\end{array}$ & No \\
\hline 2 & TV & Native & Injection drug use & TVR & NSR & $\mathrm{CHB}$ & Yes \\
\hline 3 & TV & Native & Injection drug use & TVR & ST, RBBB & CHB & Yes \\
\hline 4 & TV & Prosth & Other/none & TVR & Incomplete RBBB & $\mathrm{CHB}$ & Yes \\
\hline 5 & TV & Native & Injection drug use & TVR & ST & CHB & Yes \\
\hline 6 & TV & Prosth & Injection drug use & TVR & ST, RBBB & CHB & Yes \\
\hline 7 & TV & Native & Other/none & $\begin{array}{l}\text { TV repair, } \\
\text { VSD closure }\end{array}$ & NSR & $\begin{array}{c}\text { Intermittent } \\
\mathrm{CHB}\end{array}$ & Yes \\
\hline 8 & TV & Native & Other/none & TVR & NSR & CHB & Yes \\
\hline 9 & TV & Native & Injection drug use & TVR & $\begin{array}{c}\text { NSR, Incomplete } \\
\text { RBBB }\end{array}$ & CHB & Yes \\
\hline \multicolumn{8}{|c|}{ Left- and right-sided IE } \\
\hline 1 & $\mathrm{PV}, \mathrm{AV}$ & All native & Other/none & $\begin{array}{l}\text { AVR, PVr, } \\
\text { VSD closure }\end{array}$ & NSR & CHB & Yes \\
\hline 2 & $\mathrm{TV}, \mathrm{AV}, \mathrm{MV}$ & All native & Other/none & AVR, MVr, TVR & ST & $\mathrm{CHB}$ & Yes \\
\hline 3 & $\mathrm{TV}, \mathrm{AV}, \mathrm{MV}$ & All native & Other/none & AVR, MVr, TVr & NSR & $\mathrm{CHB}$ & Yes \\
\hline
\end{tabular}

$E C G$, Electrocardiogram; $P P M$, permanent pacemaker; $I E$, infective endocarditis; $T V$, tricuspid valve; $T V R$, tricuspid valve replacement; $S T$, sinus tachycardia; $N S R$, normal sinus rhythm; $C H B$, complete heart block; $R B B B$, right bundle branch block; Prosth, prosthetic; $V S D$, ventricular septal defect; $P V$, pulmonary valve; $A V$, aortic valve; $A V R$, aortic valve replacement; $P V r$, pulmonary valve repair; $M V$, mitral valve; $M V r$, mitral valve repair; $T V r$, tricuspid valve repair.

TABLE E6. Incremental risk factors for late mortality after surgery for right-sided infective endocarditis

\begin{tabular}{lccc}
\hline \multicolumn{1}{c}{ Factor } & Coefficient \pm SE & $\boldsymbol{P}$ & $\begin{array}{c}\text { Reliability } \\
(\%) *\end{array}$ \\
\hline eGFR $\dagger$ & $-0.67 \pm 0.18$ & .0002 & 90 \\
Mitral valve affected & $0.73 \pm 0.29$ & .01 & 58 \\
Tricuspid valve replacement & $0.90 \pm 0.28$ & .001 & 71 \\
Peripheral arterial disease & $1.3 \pm 0.33$ & $<.0001$ & 61 \\
Predisposing condition & & & \\
$\quad$ Injection drug use & $0.14 \pm 0.38$ & .7 & Forced in \\
$\quad \begin{array}{l}\text { Chronic vascular access } \\
\quad \text { Cardiac implantable }\end{array}$ & $0.011 \pm 0.29$ & .9 & Forced in \\
$\quad$ device & $0.43 \pm 0.37$ & .2 & Forced in \\
\hline SE Standard error; $e G F R$, estimated glomerular filtration rate *Percent of times fac-
\end{tabular}

tor appeared in 1000 bootstrap models. †Logarithmic transformation. 
TABLE E7. Details of relapse/reinfection after surgery for right-sided infective endocarditis

\begin{tabular}{|c|c|c|c|c|c|c|c|}
\hline $\begin{array}{l}\text { Patient } \\
\text { No. }\end{array}$ & $\begin{array}{c}\text { Time from } \\
\text { index } \\
\text { operation (mo) }\end{array}$ & $\begin{array}{l}\text { Predisposing } \\
\text { condition }\end{array}$ & Index procedures & $\begin{array}{c}\text { Reoperation } \\
\text { procedures }\end{array}$ & $\begin{array}{c}\text { Index operation } \\
\text { organism }\end{array}$ & $\begin{array}{c}\text { Recurrence } \\
\text { organism }\end{array}$ & $\begin{array}{l}\text { Relapse or } \\
\text { reinfection }\end{array}$ \\
\hline 1 & 1 & Other/none & AVR, MVr, TVr & Allo AVR, Fistula repair & $\begin{array}{c}\text { Pathogen not } \\
\text { identified }\end{array}$ & $\begin{array}{c}\text { Pathogen not } \\
\text { identified }\end{array}$ & Likely relapse* \\
\hline 2 & 1 & Injection drug use & $\mathrm{TVr}$ & $\begin{array}{l}\text { Allo AVR, TVr, } \\
\text { PFO closure }\end{array}$ & $\begin{array}{c}\text { Pathogen not } \\
\text { identified }\end{array}$ & $\begin{array}{c}\text { Pathogen not } \\
\text { identified }\end{array}$ & Likely relapse* \\
\hline $3 \dagger$ & 3 & Injection drug use & $\mathrm{MVr}, \mathrm{TVr}$ & MVR, TVR & $S$ aureus & $S$ aureus & Relapse \\
\hline 4 & 3 & Injection drug use & TVR & TVR & $S$ aureus & $S$ aureus & Relapse \\
\hline 5 & 4 & Injection drug use & AVr, TVR & AVr, TVR & MRSA & MSSA & Reinfection \\
\hline 6 & 6 & $\begin{array}{l}\text { Cardiac implantable } \\
\text { device }\end{array}$ & $\mathrm{MVr}, \mathrm{TVr}$ & MVR & $\begin{array}{c}\text { M chenolae- } \\
\text { abscessus } \\
\text { complex }\end{array}$ & $\begin{array}{c}M \text { chenolae- } \\
\text { abscessus } \\
\text { complex }\end{array}$ & Relapse \\
\hline 7 & 9 & Other/none & Allo AVR, TVr & Allo AVR & E faecalis & C krusei & Reinfection \\
\hline $8 \ddagger$ & 10 & Injection drug use & MVR, TVr & - & $S$ aureus & E faecium & Reinfection \\
\hline 9 & 11 & Injection drug use & TVR & TVR & $S$ aureus & E faecalis & Reinfection \\
\hline $3 \dagger$ & 13 & Injection drug use & MVR,TVR & MVR, TVR & $S$ aureus & E fecalis & Reinfection \\
\hline 10 & 14 & Injection drug use & MVR, TVr & MVR & $S$ aureus & $R$ mucilaginosa & Reinfection \\
\hline 11 & 20 & Injection drug use & MVR, TVr & MVR, TVr & $S$ aureus & C albicans & Reinfection \\
\hline $12 \ddagger$ & 23 & Injection drug use & $\mathrm{TVr}$ & - & $S$ aureus & $P$ aeruginosa & Reinfection \\
\hline 13 & 56 & Other/none & TVR & Allo AVR, TVR & $S$ aureus & $S$ aureus & Reinfection \\
\hline
\end{tabular}

$A V R$, Aortic valve replacement; $M V r$, mitral valve repair; $T V r$, tricuspid valve repair; Allo, allograft; $P F O$, patent foramen ovale; $M V R$, mitral valve replacement; $T V R$, tricuspid valve replacement; $A V r$, aortic valve repair; MRSA, methicillin-resistant Staphylococcus aureus; MSSA, methicillin-sensitive Staphylococcus aureus; TV, tricuspid valve. *In 2 cases, the pathogen was not identified at index operation or reoperation; however, reoperation was performed within 1 month of index operation. These were deemed "likely relapse." †Patient was treated for recurrent IE twice at this institution. ‡All patients underwent reoperation for recurrent IE except \#8 and \#12, who were treated medically. 